\title{
Gene Mining for Proline Based Signaling Proteins in Cell Wall of Arabidopsis thaliana
}

\begin{abstract}
Muhammad Z. Ihsan ${ }^{1}$, Samina J. N. Ahmad ${ }^{2,3 *}$, Zahid Hussain Shah ${ }^{4}$, Hafiz M. Rehman ${ }^{5}$, Zubair Aslam ${ }^{6}$, Ishita Ahuja ${ }^{7}$, Atle M. Bones ${ }^{7}$ and Jam N. Ahmad ${ }^{2,3}$

${ }^{1}$ Cholistan Institute of Desert Studies, The Islamia University Bahawalpur, Bahawalpur, Pakistan, ${ }^{2}$ Plant Stress Physiology and Molecular Biology Lab, Department of Botany, University of Agriculture Faisalabad, Faisalabad, Pakistan, ${ }^{3}$ Integrated Genomics Cellular Developmental and Biotechnology Lab, Department of Entomology, University of Agriculture Faisalabad, Faisalabad, Pakistan, ${ }^{4}$ Department of Arid Land Agriculture, Faculty of Meteorology, King Abdulaziz University, Jeddah, Saudi Arabia, ${ }^{5}$ Department of Electronic and Biomedical Engineering, Chonnam National University, Gwangju, South Korea,

${ }^{6}$ Department of Agronomy, University of Agriculture Faisalabad, Faisalabad, Pakistan, ${ }^{7}$ Department of Biology, Norwegian University of Science and Technology, Trondheim, Norway
\end{abstract}

The cell wall $(\mathrm{CW})$ as a first line of defense against biotic and abiotic stresses is of

OPEN ACCESS

Edited by:

Susan Jones,

James Hutton Institute, UK

Reviewed by:

Dapeng Wang,

University of Oxford, UK

Sergio J. Ochatt,

Institut National de la Recherche

Agronomique-UMR 1347

Agroécologie, France

*Correspondence:

Samina J. N. Ahmad

saminatmalik@yahoo.com;

Jamnazire@yahoo.com

Specialty section:

This article was submitted to Bioinformatics and Computational

Biology,

a section of the journal

Frontiers in Plant Science

Received: 08 July 2016 Accepted: 07 February 2017 Published: 27 February 2017

Citation:

Ihsan MZ, Ahmad SJN, Shah ZH, Rehman HM, Aslam Z, Ahuja I, Bones AM and Ahmad JN (2017) Gene Mining for Proline Based Signaling Proteins in Cell Wall of

Arabidopsis thaliana.

Front. Plant Sci. 8:233.

doi: 10.3389/fp/s.2017.00233 primary importance in plant biology. The proteins associated with cell walls play a significant role in determining a plant's sustainability to adverse environmental conditions. In this work, the genes encoding cell wall proteins (CWPS) in Arabidopsis were identified and functionally classified using geneMANIA and GENEVESTIGATOR with published microarrays data. This yielded 1605 genes, out of which 58 genes encoded proline-rich proteins (PRPs) and glycine-rich proteins (GRPs). Here, we have focused on the cellular compartmentalization, biological processes, and molecular functioning of proline-rich CWPs along with their expression at different plant developmental stages. The mined genes were categorized into five classes on the basis of the type of PRPs encoded in the cell wall of Arabidopsis thaliana. We review the domain structure and function of each class of protein, many with respect to the developmental stages of the plant. We have then used networks, hierarchical clustering and correlations to analyze co-expression, co-localization, genetic, and physical interactions and shared protein domains of these PRPs. This has given us further insight into these functionally important CWPs and identified a number of potentially new cell-wall related proteins in $A$. thaliana.

Keywords: Arabidopsis, co-expression, geneMANIA, GENEVESTIGATOR, kinase, proline

\section{THE PLANT CELL WALL}

The cell wall (CW), considered as first line of defense in plants, is composed of polysaccharides (cellulose, hemicellulose, pectin), and proteins. These proteins can either be structural or nonstructural depending upon their functionality. Since the first report of cell wall proteins (CWPs) in Hydrodictyon africanumin (Northcote et al., 1960), hundreds of proteins have been identified which serve as an integral structural part (about 10\% of wall dry weight) and perform multiple functions in various signaling pathways.

CWPs have key importance in sensing environmental stresses and controlling CW dynamics in response to the growth and development of the plant. However, currently we have a limited understanding of the structure, function and interaction of CWPs, and also very little knowledge 
of association of cuticle with plants reactive phytochemicals (Ahuja et al., 2016). Proline rich proteins (PRPs), proline rich extensin like proteins (PRExts), hydroxy-proline rich O-glycoproteins (HRGPs), expansins, and formin like proteins are some of the known classes of CW proteins with covalent scaffold and glycosylation as their known interactions (Boron et al., 2014; Suzuki et al., 2015). Arabidopsis thaliana is a model plant comprising of five chromosomes with 33,542 genes, where 1,605 genes are responsible for the CW development. Out of these 1,605 genes, 252 are responsible for cellulose, 10 for hemicellulose, and 317 for pectin regulation (Albenne et al., 2013). In this review, we have mainly described PRPs, which are the pivotal constituent of the $\mathrm{CW}$ together with mining of genes behind these proteins. Along with this, we have attempted to build wired networks to see how these genes co-express and interact in regulating PRPs during the biological and physical processes as well as in determining the molecular functions. We have used the gene mining approach to identify 58 genes located on different chromosomes (Figure 1). These genes are either directly or indirectly involved in the regulation of proline related proteins in the CW under various biotic and abiotic stresses. We have classified these genes into five groups based on their expression for the different structural and functional proteins (Figure 2). Moreover, schematic diagrams (using GeneMANIA and GENEVESTIGATOR) have been generated for the networks of gene co-expression, gene co-localization, genetic interaction, physical interaction, shared protein domains, and predicted interaction (Figures 2-8). A heat map, genome array, Pearson's correlation coefficient (PCC) and hierarchical clustering are also presented for the selected genes for an estimation of the genetic interactions and their level of co-expressions at different plant developmental stages and in the various plant anatomical parts.

\section{CELL WALL PROTEINS (CWPS)}

The CWPs are divided into nine classes based on their signaling events (Albenne et al., 2013). They are linked to the several important pathways including lipid and carbohydrate metabolism, structural components, proteolytic andoxidoreductive activity, cell signaling, molecular interaction, miscellaneous, and the proteins with an unknown activity.

The CWPs involved in cell signaling, in response to abiotic stresses, have been extensively studied. Under such stress conditions, the major classification of CWPs include the salt overly sensitive kinases, phospholipases, transcription factors,

\footnotetext{
Abbreviations: CW, cell wall; CWPs, cell wall proteins; APG, adelaide protein group; At, Arabidopsis thaliana; APAP1, arabinoxylan pectin arabinogalactan protein1; FLA, fasciclin-like arabinogalactan; GUS2, glucuronidase; GP1, glycosyl phosphatidyl inositol; Hyp, hydroxyproline; LRKs, leucine rich repeats receptor like kinases; PTMs, post translational modifications; PRExts, proline rich extensin like proteins; PERKs, proline rich extensin like receptor kinases; LecRKs, lectin receptor kinases; P4Hs, prolyl 4-hydroxylases; P5CR, pyrroline-5-carboxylate reductase; RANBP, ran binding protein; PRPs, proline rich proteins; HRGPs, hydroxy-proline rich O-glycoproteins; AGPs, arabinogalactan proteins; CWAKs, cell wall associated kinases; ROS, reactive oxygen species; Asp, aspartate; Cys, cysteine; GRPs, glycine rich proteins; EXTs, extensions; FLAs, fasciclin-like AGPs; THRGP, threonine-rich hydroxyproline-rich glycoprotein; Tyr, tyrosine; DNA, deoxyribonucleic acid.
}

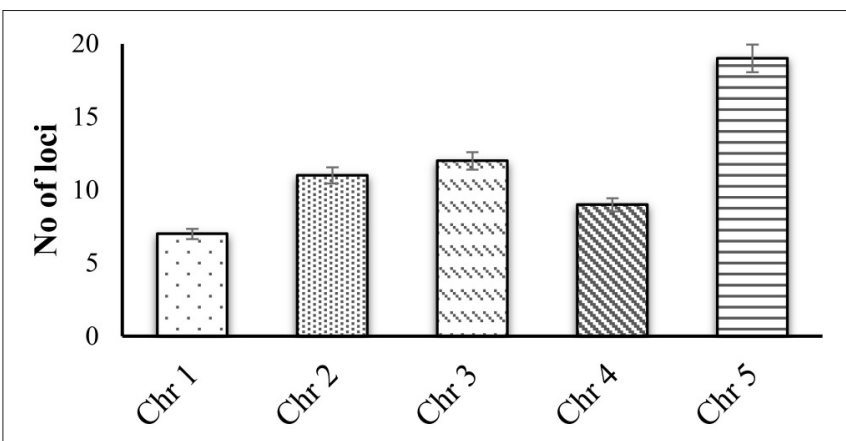

FIGURE 1 | Gene mining approach for identification genes that are involved in proline based regulation in CW of Arabidopsis thaliana.

dehydration responsive element binding proteins, C-repeat binding factor, mitogen activated proteins, and abscisic acid responsive element binding factors (Vinocur and Altman, 2005). The involvement of CW in different stress reception mechanisms is not surprising. Kinases are perceived as potential candidates for the CW sensor (Steinwand and Kieber, 2010). Activation of various kinases in response to the changing levels of the same stress has already been well-reported (Kacperska, 2004). In $A$. thaliana, 26 genes related to the $\mathrm{CW}$ associated kinases (CWAKs), and similar functions have been reported (Verica and $\mathrm{He}, 2002)$. In addition to the abiotic stresses, CWAKs are also involved in the plant defense against pathogens (Bellincampi et al., 2014). Recently, a number of new CWAKs have been reported, which include proline rich extensin like receptor kinases (PERKs), leucine rich repeats receptor like kinases (LRKs), and lectin receptor kinases (LecRKs) (Wolf et al., 2012). The CW plasma membrane interface is hypothesized as a key site for the stress signal perception where the interaction was studied between arabinogalactan proteins (AGPs) and receptor like kinases (Baluška et al., 2003). The production of hydrogen peroxide and downward redox signaling during the stress is an interesting aspect of CWPs (Spasojević and Pristov, 2010). The generation of reactive oxygen species (ROS) in response to CWP signaling (Barceló and Laura, 2009) is an important and interesting phenomenon, because mitochondria and chloroplast are considered as the major players of ROS production (Voothuluru and Sharp, 2013). In response to abiotic stresses, the extracellular ROS accumulation is tightly regulated by the enzymes (Jaspers and Kangasjärvi, 2010) in cell membrane, which in turn are tightly bonded to the CW (Plieth, 2012). The speedy response of the CW (associated with the changes in its composition or structure) has led researchers to make a detailed study of the various functional proteins with an enzymatic activity within the CW. These include the CW formation, reorganization, loosening and carbohydrate metabolism (Brown et al., 2005; Gupta et al., 2005; Sasidharan et al., 2011; Xu et al., 2014).

Collectively, 2,170 CWPs have been identified on the basis of their distinct gene expression in various plants (San Clemente and Jamet, 2015). The glycoside hydrolases, lyases, esterases, and hydrolases come under the umbrella of proteins acting 
Arabidopsis thaliana genome

NCBI

Gene mining for proline regulation responsible genes

TAIR

Shortening based on cell wall compartmentalization

Expression

1. Hydroxyproline rich glycoproteins (HRGPs)

2. Proline rich extensins (PRExts)

3. Arabino galactans proteins (AGPs)

4. Hybrid proline rich proteins (HyPRPs)

Glycine rich proteins (GRPs)
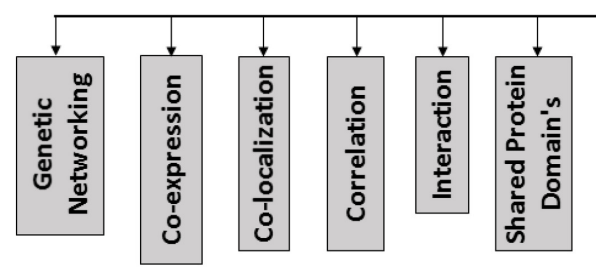

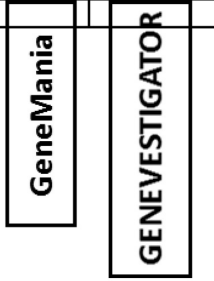

\begin{tabular}{|c|}
\hline \\
\hline
\end{tabular}

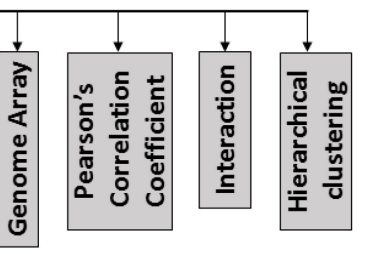

FIGURE 2 | A schematic diagram to show the flow of proline based genes regulation in CW of Arabidopsis thaliana.

on polysaccharides (Jamet et al., 2008). The other class of oxidoreductases contains blue copper binding proteins, multicopper oxidases and peroxidases, while the proteases consist of Aspartate (Asp) proteases, ser carboxy peptidases, and cysteine (Cys) proteases. The oxidoreductases are an important class of enzymes that transfer $\mathrm{OH}$ group at critical physiological stages of plant development and affect the structure of the CW (Fry, 1998). Lipid transfer proteins are involved in lipid metabolism (Lev, 2010), and the AGPs in stress signaling (Shen et al., 2001). While, extensins (EXTs) and glycine rich proteins (GRPs) are the structural proteins. Some proteins, grouped as miscellaneous class like germin and germin like proteins, phosphatases and the phosphate inducible proteins, are still unclassified (Shahzad et al., 2013).

The in silico analyses showed 58 genes responsible for the regulation of proline based proteins in the $\mathrm{CW}$ of $A$. thaliana (Figure 3). The gene interaction and co-expression in the form of a wired network has been constructed for the cellular component and biological and molecular process. A significant variability has been observed in the degree of physical interactions, predicted interactions, co-expressions, genetic interactions, shared protein domains, and co-localization.

\section{Hydroxy-Proline Rich O-Glycoproteins (HRGPs)}

The HRGPs were recognized several decades earlier than the CWPs and marked as the complex macromolecules based on their chemistry and functionality (Wang et al., 2012). Based on glycosylation, HRGPs are categorized into three subclasses. These classes are hyper-glycosylated AGPs, moderately glycosylated EXTs and hyper PRPs (Tan et al., 2004). The HRGPs showed a specific multitude of functionalities. The cell signaling, defense, embryogenesis, development, reproduction, and expression are some of the recognized functions of AGPs (Seifert and Roberts, 2007). The EXTs are involved in the covalent scaffold and portrayed as the structural proteins of the CW (Cannon et al., 2008). The PRPs are the least developed proteins, and linked with the numerous biotic and abiotic stresses (Battaglia et al., 2007). The diversity of HRGPs further enhanced the addition of hybrid and chimeric proteins into the HRGPs family (Showalter et al., 2010). The gene mining of A. thaliana has revealed that 166 genes are encoding HRGPs, whereas 85 genes encode AGPs, 59 genes EXTs, 18 genes PRPs, and 4 genes hybrid proteins (Showalter et al., 2010). More than 50 genes were identified on the basis of their involvement in proline regulation in the $\mathrm{CW}$ for the 15 different functions. Even after more than 60 years of research, the detailed expression and functioning of HRGPs has not been clarified (Léonard et al., 2010). Several classes of the proteins share common function and sometimes a single class in the CW controls more than one function (Jamet et al., 2006). The AGPs are considered as the signaling proteoglycans but also sometime implicated to link the CW to the plasma lemma (Ellis et al., 2010). The EXTs play a vital role in the CW architecture (Lamport et al., 2011).

The HRGPs are evidently involved in growth, development, embryogenesis, apoptosis, and the CW architecture (Tan et al., 2012). The AGPs can be further divided into several classes, which may belong to the classical AGPs, non-classical AGPs, AG peptides, Lys-rich AGPs, Fasciclin-like AGPs (FLAs), and chimeric AGPs (Schultz et al., 2002). The AGPs attached to 


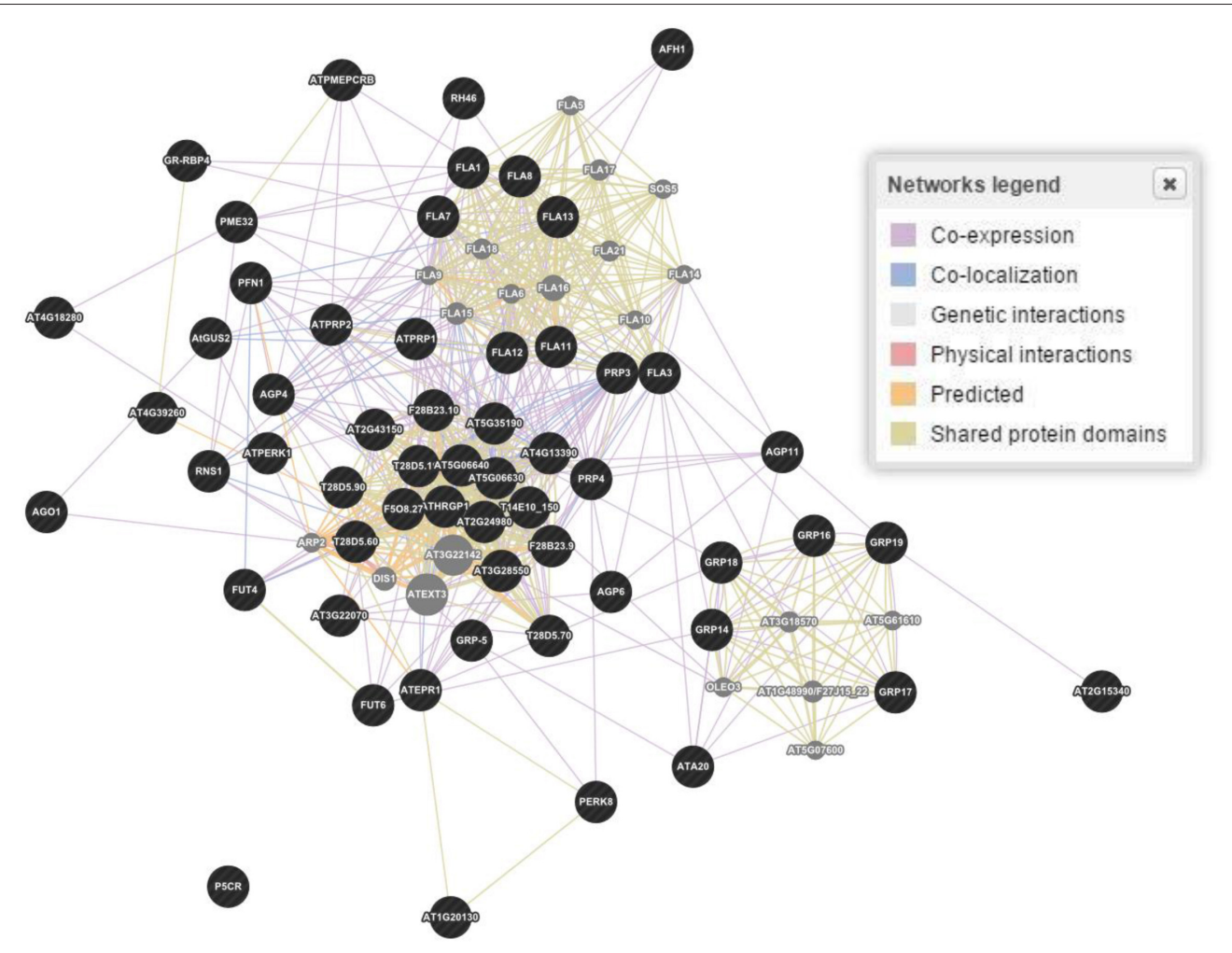

FIGURE 3 | Gene and interaction networks for molecular functioning of genes involved in regulation of proline based cell wall proteins in Arabidopsis thaliana. Physical interactions 55.7, 7.4, and 39.0\%; Predicted interaction 17.5, 30.7, and 30.8\%; Co-expression 15.6, 55.9, and 11.8\%; Genetic interactions 6.9, 1.1, and 3.3\%; Shared protein domains 3.6, 2.9, and 14.6\%; Co-localization 0.6, 1.8, and 0.4\% were estimated for genes biological processes, cellular components and molecular functions, respectively. Figure represents molecular functions networks as a reference. Dark (black) spots highlight genes interacting for a specific family of proteins, while light (gray) spots represent those genes whose interactions were not considered.

the cell membranes (Gaspar et al., 2001), are encoded by 69 genes involved in the stress signaling and cellular processes (Ma and Zhao, 2010). The EXTs, under the pathogenic attack, were engaged in the peroxidase mediated cross-link to reduce its permeability (Cannon et al., 2008). To face stress in a better way (Ihsan et al., 2016), plant cells accumulate osmolytes (hydro-soluble carbohydrates) and proline to combat a water loss (Yamaguchi and Blumwald, 2005). Proline is synthesized from glutamate via a two-step oxido-reductase pathway involving the pyrroline-5-carboxylate synthase (P5CS) $\gamma$-glutamyl kinase $(\gamma$ GK), and glutamic- $\gamma$-semialdehyde dehydrogenase (GSA-DH; Chen et al., 2009). Increase in proline in response to stress is associated with the upregulation of its biosynthetic genes (Silva-Ortega et al., 2008). Thus, both proline levels and the expression of P5CS are useful markers for assessing the levels of stress acclimation through modifications in structure of the CW. It has been reported that overexpression of a novel feedbackdesensitized $\Delta$ 1-pyrroline-5-carboxylate synthetase increased proline accumulation in transgenic Nicotiana plumbaginifolia thereby conferring the salt tolerance in this plant (Ahmed et al., 2015).

The wired networking of genes, constructed through GENEVESTIGATOR, revealed a high extent of interaction and co-expression of clusters of genes controlling these classes of proteins (Figure 4). Differential interaction and co-expression has been observed between the genes for biological processes, molecular functions and cellular compartmentalization.

\section{Proline Rich Extensin like Proteins (PRExts)}

The PRExts are characterized partially in the superfamily of HRGPs and are implied in the assemblage of the CW and promotion of the cell growth and shape (Sasidharan et al., 2011). They have been studied extensively in previous decades (de Caestecker et al., 2000; Silva and Goring, 2002; Hsu et al., 2005; Bai et al., 2009). They formulate a highly known CWPs family. These are basic pectin interacting proteins containing Hyp O-glycosylated with short arabino-oligosaccharides. They can configure a helical structure named polyproline II, crosslinked through isodityrosine or di-isodityrosine (Choe and Cosgrove, 2010). In vitro scrutiny of atomic force microscopy has explored the pure form of A. thaliana "EXT3" constituting branchy structures, consistently cross-linked by the peroxidases (Geilfus et al., 2010). Likewise, threonine-rich hydroxyprolinerich glycoprotein (THRGP) found in maize were not crossallied by the peroxidases. It was anticipated that the positive charged scaffolds produced by the assembly of EXTs in cell plates of the cell wall positively react with charged pectin through an ionic force. The presence of covalent interactions 


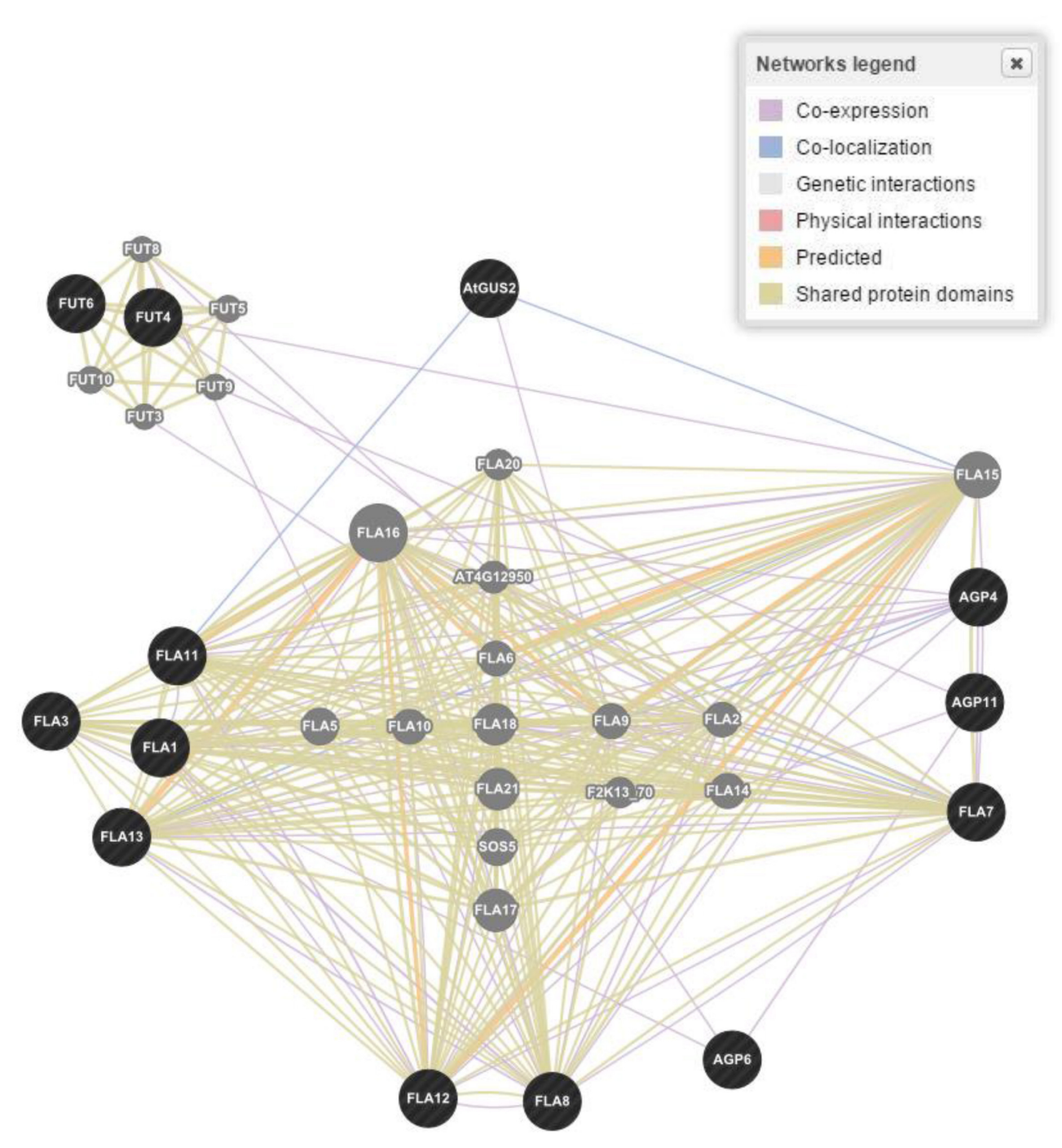

FIGURE 4 | Gene networking and interactions for one of the four responsible gene families based on biological process, molecular functions and cellular components in Arabidopsis thaliana. Figure represents only proline rich proteins class as a reference. Dark (black) spots highlight genes interacting for a specific family of proteins, while light (gray) spots represent those genes whose interactions were not considered.

has also been proposed between EXTs and pectin. It has been found that a three dimensional covalent network was formed by the EXTs via Tyrosine (Tyr) linkages mediated by EXT (Cannon et al., 2008). The EXT monomers assemble in the $\mathrm{CW}$ in terminal zipper like organization through a cross linkage (Lamport et al., 2011). It is projected that an EXT associated with pectin further blossoms cell wall through an acid base reaction by forming a supra-molecular ionic structure. The EXTs constitute a three dimensional network of the glycoproteins with a pectin component of the CW (Voragen et al., 2009). The occurrence of the EXTs like chimeras and hybrid EXTs have also been confirmed in the CW (Showalter et al., 2010). Despite of the EXTs insolubility, their behavior has also been modified by the other domains of the proteins.
The characteristics articulated by the EXTs were just like the collagen cross-linked forming motifs (Lodish et al., 1999). However, contrary to collagen, the EXTs exhibit a plant specific post translational feature named $O$-glycosylation on the SerHyp motifs. The experimental methodologies opted through molecular dynamics and homology modeling, recommended that classical EXTs would form a triple helical structure via the lateral staggered configuration and a Tyr cross-linking analogous to the collagen (Cannon et al., 2008). In the genome of $A$. thaliana, EXT is mentioned in the form of 59 members, like classical, chimeras and hybrids occupied by the different domains. No doubt, high number of EXT domains are residing in the CW but a little is known about their exact functionality and diversity during the plant developmental stages (Lamport et al., 2011). The analogous and repetitive sequences of proteins, 


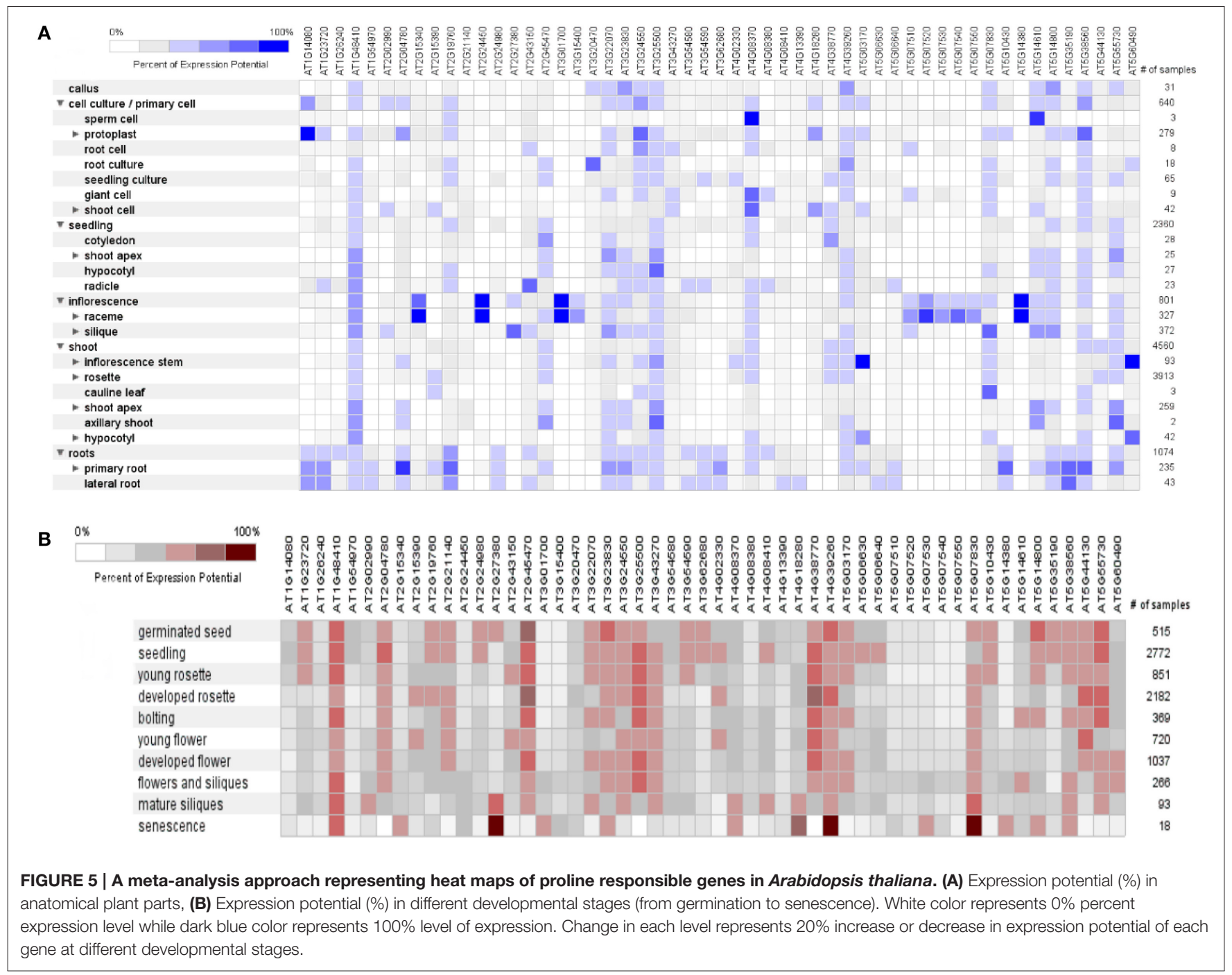

encoding of a large number of proteins in same genome and simultaneous expression of the genes in the same tissue of plant are the different grounds that had created difficulty for us to perceive the exact biology of the EXTs.

The O-glycoproteins possessing EXT domains were finally integrated in the $\mathrm{CW}$, put together by the different post translational modifications (PTMs), comprising processing of signal peptide by endoplasmic reticulum, proline hydroxylation, O-glycosylation, and Tyr cross linking in the CW (Nguema-Ona et al., 2014). In the past few years, research has revealed that several enzymes were involved in EXT fabrication pathways as a part of their PTMs. Even a small change in O-glycosylation status of EXTs affected the expansion of the polarized cell as observed by a drastic root hair appearance in mutants in response to the absence of glycosyltransferase (Velasquez et al., 2011). It has been reported that both types of the $O$-glycosylation located in the EXTs, were needed for the correct functionality of the EXTs during the root elongation. Somehow, it is not certain how the EXT monomer assembled into glycol-network and how the EXT pectin interactions are regulated during the nascent
CW formation (Micheli, 2001). Through bioinformatics tools, we have found 21 genes encoding the EXTs like proteins in the CW that determined its structural architect at the molecular level and were expressed in different parts of the plant (Table 1).

\section{Arabinogalactan Proteins (AGPs)}

The AGPs are proteoglycans found in nearly all tissues and exudates of higher plants (Youl et al., 1998). These are 90\% polysaccharides by composition and can be extracted in a low salt buffer and have been reported as non-structural part of the CW matrix (Fincher et al., 1983). These proteins belonged to the highly diversified hydroxyl proline-rich glycoproteins superfamily (Velasquez et al., 2011) in the plant kingdom (Seifert and Roberts, 2007). In Arabidopsis, the AGPs have been classified into 22 classes on the basis of their proteoglycan formation cohering with various developmental processes in plants (Showalter et al., 2010). However, the pectin and cellulose form the network structured by AGPs (Jia et al., 2015), which maintains the structural integrity of the CW. Moreover, the higher plant CWs constituted by cellulose micro-fibrils in 
A

AT1914080 AT1623720 AT1626240 AT1948410 AT1G54970

AT2G02990 AT2 604780 AT2G15340 AT2G15390 AT2G19760
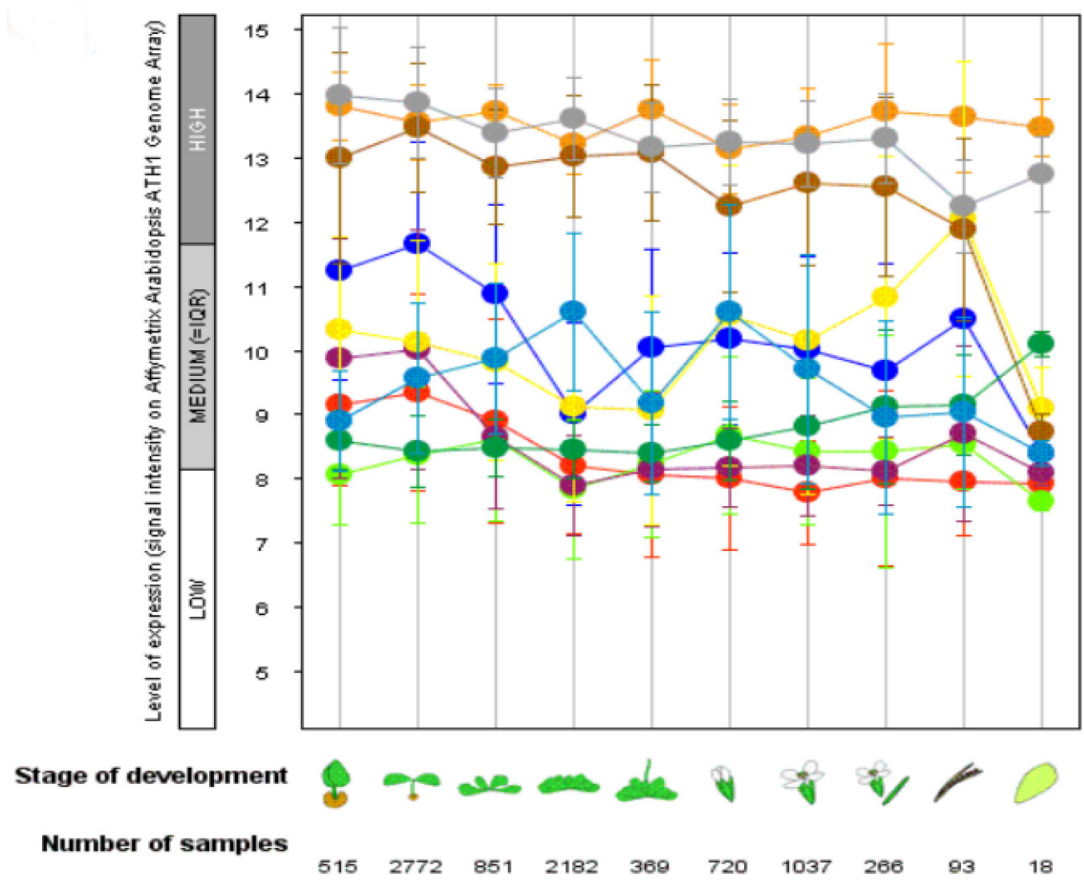

B

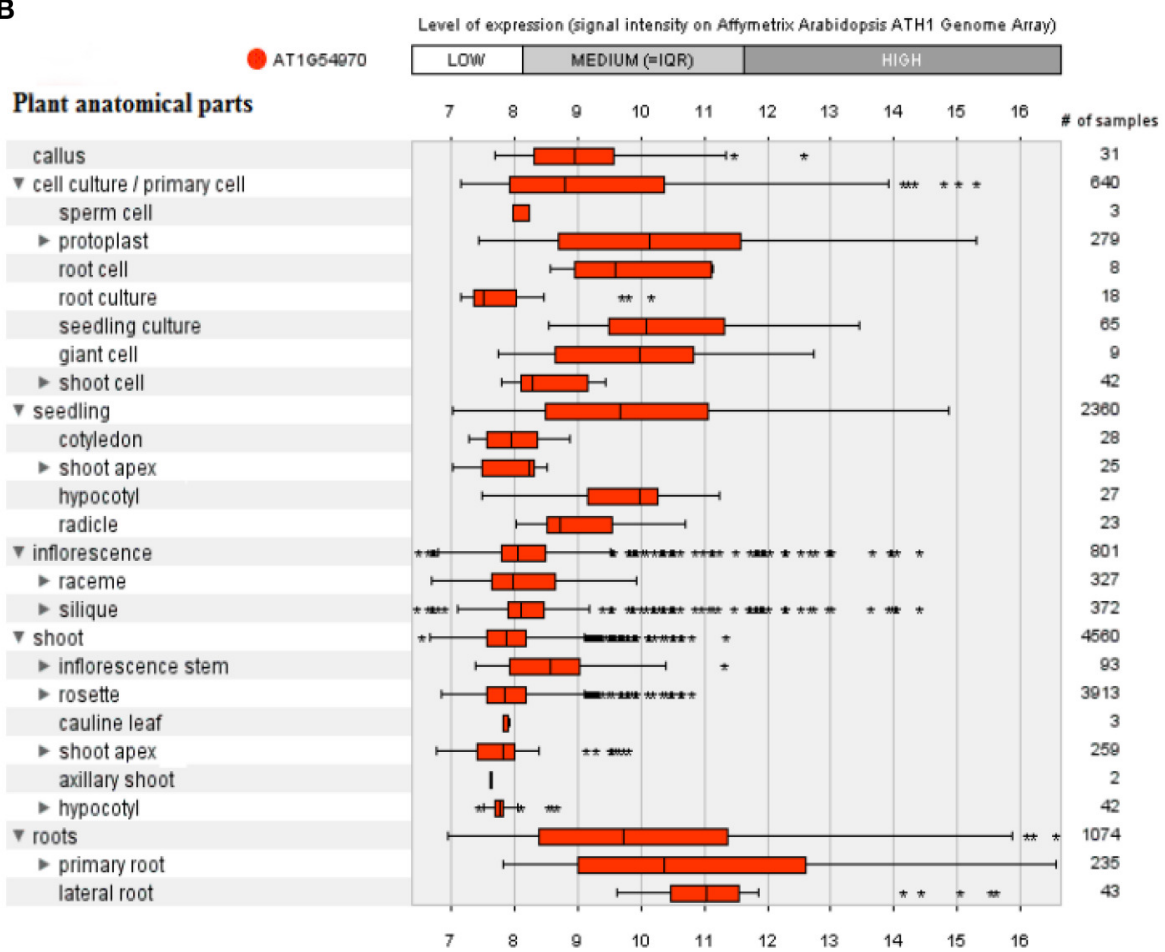

FIGURE 6 | A genome array map representing levels of expression of 10 selected genes at different developmental stages and a single selected gene for different anatomical parts in Arabidopsis thaliana. (A) Levels of expression at different developmental stages (from germination to senescence), which has been analyzed against different number of samples. (B) Expression level of a single selected gene AT1G54970 (PRP1) in 27 anatomical parts. Bars represent standard error at $P \leq 0.05$. 

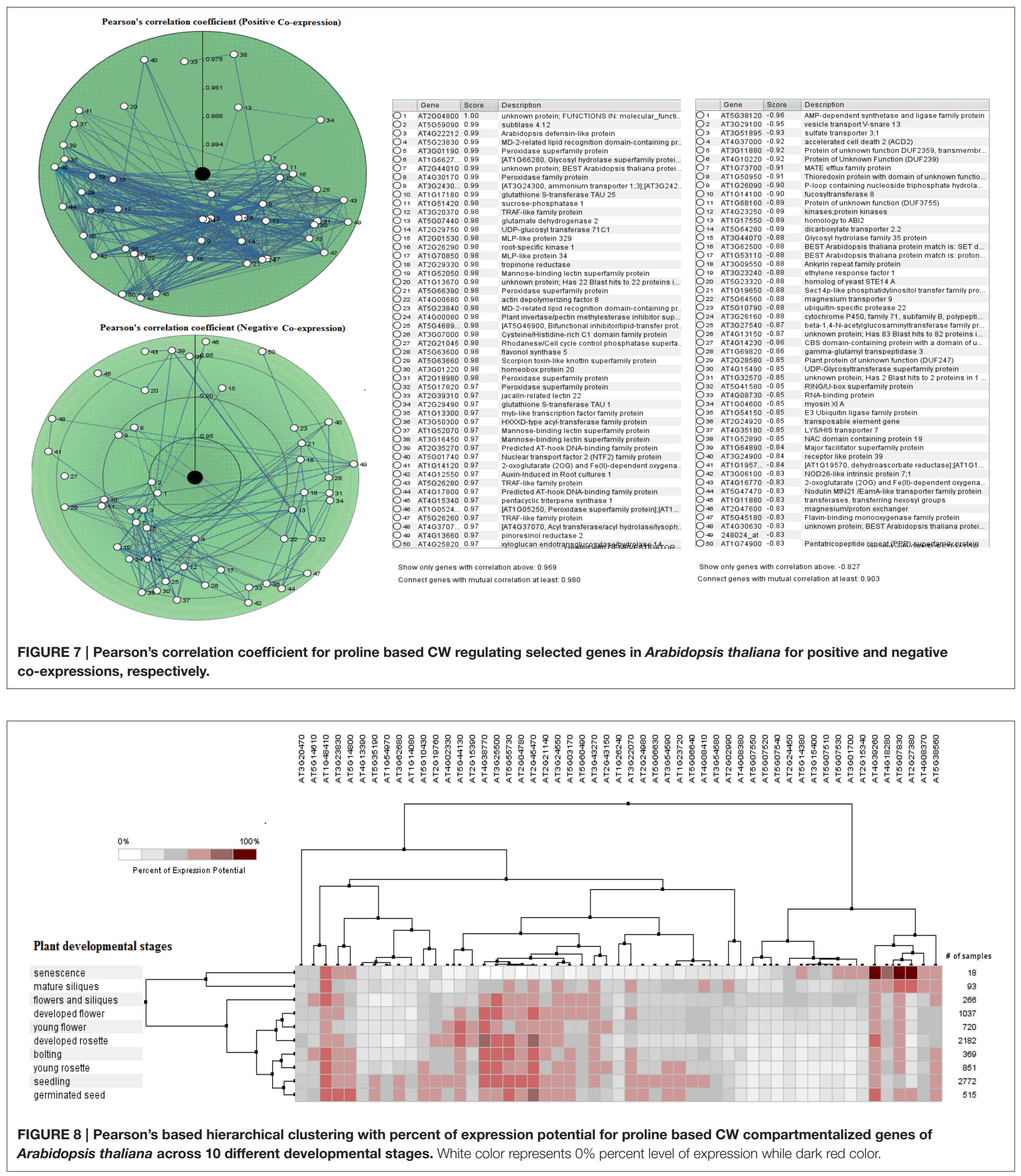

glycoproteins, pectin and cellulose maintained the functional features, integrity and strength of the CW (Schwager et al., 2007; Ellis et al., 2010). Various studies have confirmed the prevalence of association between AGPs and pectin's from plants tissue e.g., grapes, carrot and sugar beet. Co-localization of pectin's and AGPs has been observed in the pollen tube (Mollet et al., 
2002). When a plant CW was treated with the pectin degrading enzymes, an increase in the release of AGPs was observed, confirming an association between AGPs and pectin (Lamport et al., 2006). The interactions have also been reported between the AGPs and polysaccharides such as AGP-xylan complexes (Keegstra et al., 1973; Kwan and Morvan, 1995). An isoform of A. thaliana AGP (At3g45230) has been shown to be covalently linked with the pectins and hemicelluloses (Tan et al., 2012). Some AGPs function as polysaccharide plasticizers as they establish a cross linkage in the CW (Lamport et al., 2006).

A few AGPs were exposed to make the covalent interactions with the CW implying its role as a cross linker and pectin plasticizer, and to constitute complexes with the pectin and xylans (Tan et al., 2012). A complex arabinoxylan pectin arabinogalactan protein1 (APAP1) formed by the covalent interaction between $A$. thaliana AGP hemi cellulosic and pectic polysaccharide, has been reported to play some structural role in the CW (Tan et al., 2013). However, it is hypothesized that AGP31 established non-covalent cohesion in networks residing within the CW and could be extracted from the CW polysaccharides. The AGPs showed prominence in the covalent linkages with the pectin and hemicelluloses to restructure an APAP1 complex (Tan et al., 2013).

The AGPs determine plant growth, cell division, necrosis, zygotic division, and embryo formation (Majewska-Sawka and Nothnagel, 2000). They also play a role in somatic embryogenesis during embryonic development of plants (Businge and Egertsdotter, 2014). In Arabidopsis, the AGPs were located in the basal part of the suspensor ( $\mathrm{Hu}$ et al., 2006). In Nicotiana, the expression of AGPs during the embryo development stage was highly regulated (Geshi et al., 2013). Moreover, the potentiality of cellulose and pectin deposition in the CW was also hampered due to disruption in the AGPs functionality. Recent studies have focused on the structure biosynthesis and functionality of the AGPs enriched by a high percentage of sugars (Kitazawa et al., 2013). Thirteen genes encoding different types of AGPs with their roles are outlined in Table 2.

\section{Hybrid Proline Rich Proteins (HyPRPs)}

The HyPRPs determine cell-type-specific wall structure during developmental phases and contribute in defensive mechanisms during the pathogenic infection. When treated with fungal elicitor, physical damage, and pathogen infection, the HyPRPs were rapidly insolubilized in the CW (Francisco and Tierney, 1990). They are a group of structural proteins formulating covalent cross linkages between the constituents of the CW (Showalter, 1993). They are further categorized on the basis of deoxyribonucleic acid (DNA) sequence similarity, continuity of motifs and domain organization (Fowler et al., 1999). The HyPRPs belonged to classical protein families with well-defined sequence but little is known about their systematic functioning. The CW based molecular mechanisms involved in evolution; ontogeny and functioning were purely based on theoretical interests albeit its major role was defined as a physical support to the cell. The HyPRPs are classified on the bases of different domains, proline rich $\mathrm{N}$ terminal repetitive, and hydrophobic
C terminal domains (Neto et al., 2013). Previous data has revealed that the expression level and stimuli for HyPRPs differ significantly owing to plant developmental stage and environmental conditions. The blast analysis of Arabidopsis genome sequence revealed the involvement of 28 HyPRPs gene loci in the CW functions (Chardon et al., 2004). All chromosomes contained HPRPs genes but the higher number had been reported on second chromosome. The expression pattern of these genes is partially conserved between closely related paralogous genes. The exact role and compartmentalization of PRPs is still not wellunderstood compared to some better-characterized families. The PRPs are least glycosylated proteins that are extremely basic with the demonstration of specific repetitive motifs. Although there is no expressive evidence, still it is predicted that PRPs were cross linked by covalent bond within the CW (Tan et al., 2003). With the help of online tools, we have reported four genes controlling different kinds of PRPs in CW of A. thaliana, which are involved in different types of molecular processes in different localities (Table 3).

\section{GLYCINE RICH PROTEINS (GRPS)}

The GRPs located within the CW of vascular tissues are regulated during the developmental stages of plants (Ye et al., 1991) by forming a third major group of CW proteins. The manifestation of many GRPs takes place under environmental stresses like water deficiency, high light, ABA, and pathogenic infestations. Although, it is presumed that GRPs were a part of the plant defense system, their mechanism of action is not yet known. It is possible that GRPs presenting other functional domains were necessary to determine how protein activity get affected under different conditions (Mangeon et al., 2010).

In plants, GRPs related genes are regulated during developmental stages and their expression varies in plant tissues (Yan et al., 2015). In different genera of plants, the expression of such genes is controlled by biotic and abiotic stresses (Ahmad et al., 2014; Alghabari et al., 2015, 2016; Ihsan et al., 2015; Yan et al., 2015). In plants, the categorization of GRPs is based on the semi-repetitive glycine rich motifs (Sachetto-Martins et al., 2000). According to a report, the French bean PvGRP1.8, a class 1 GRP, located in un-lignified primary $\mathrm{CW}$, played a structural role in protoxylem through the CW buttressing (Ryser et al., 2004). Reverse genetics approaches have fortified the concept of the involvement of GRPs gene from Arabidopsis in the deposition of the secondary CW and maintenance of proto-xylem structure (Yokoyama et al., 2007).

Undoubtedly, the diversified structure, intonation, expression, prototype, and subcellular localization of GRPs are strongly witnessed for their prominent role and functionality in plants (Sachetto-Martins et al., 2000). Observations have disclosed the involvement and modulation of GRPs in the defense mechanism under pathogenic attack (de Souza Cândido et al., 2011). The NtClG1 gene was induced in turnip whose level was altered by tobacco virus, as shown by increased deposition of cellulose, which restricted the viral movement. This implicate structural roles of GRPs in conferring defense mechanisms 


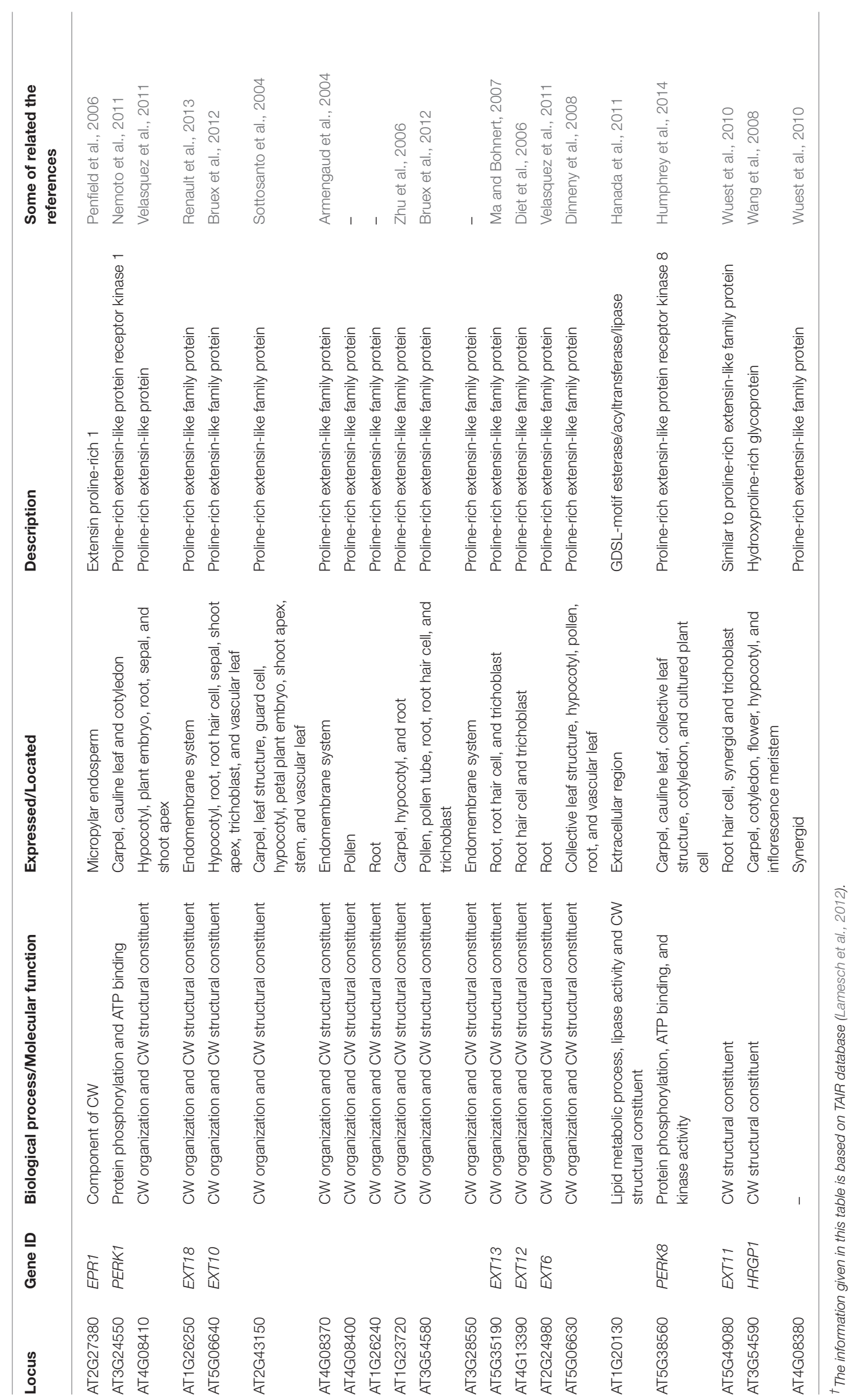




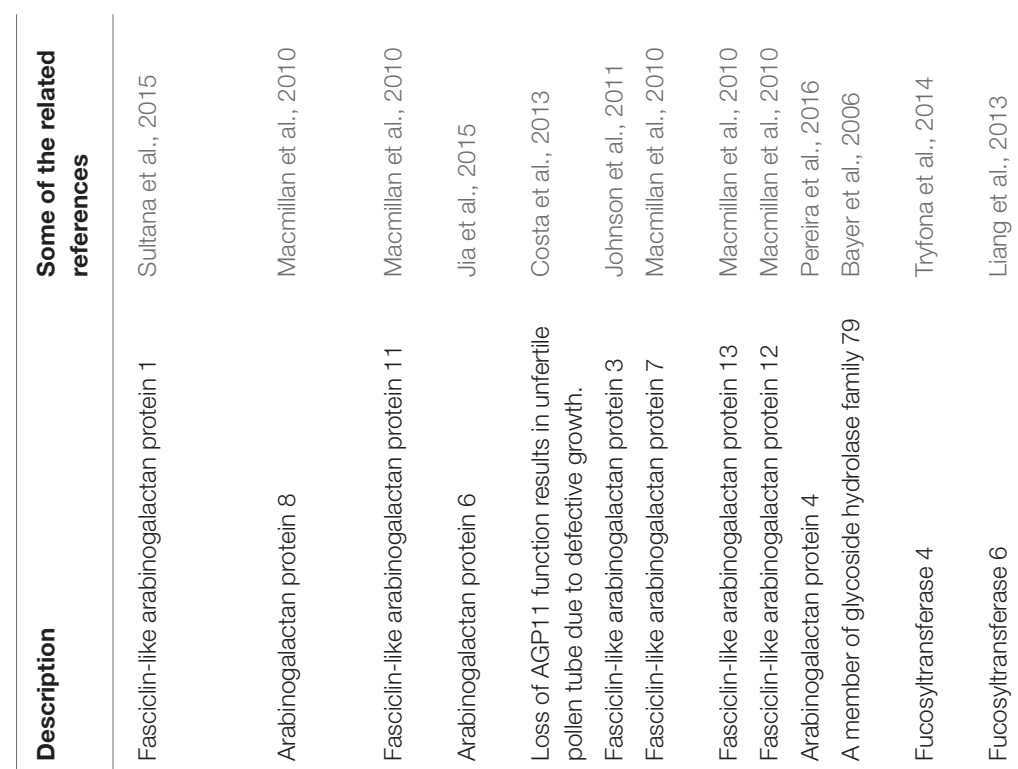

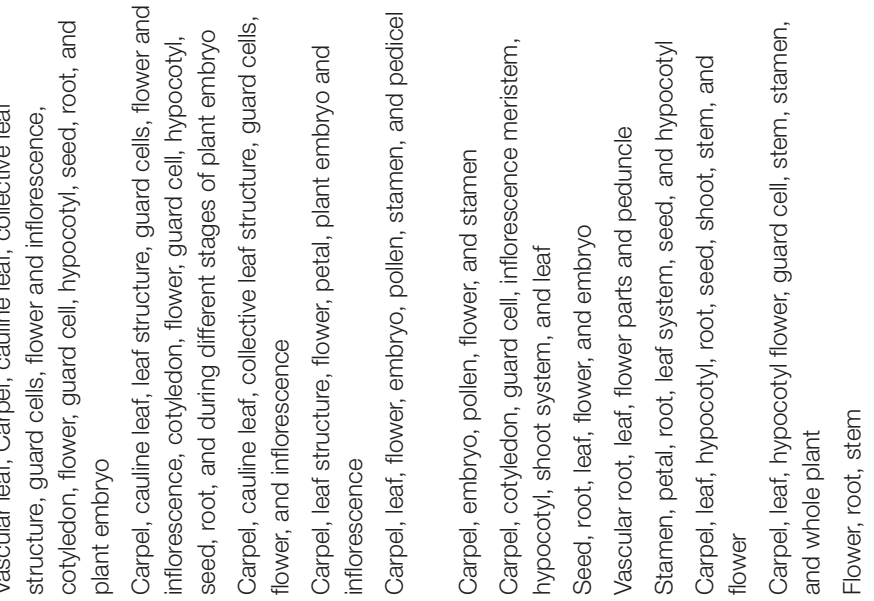

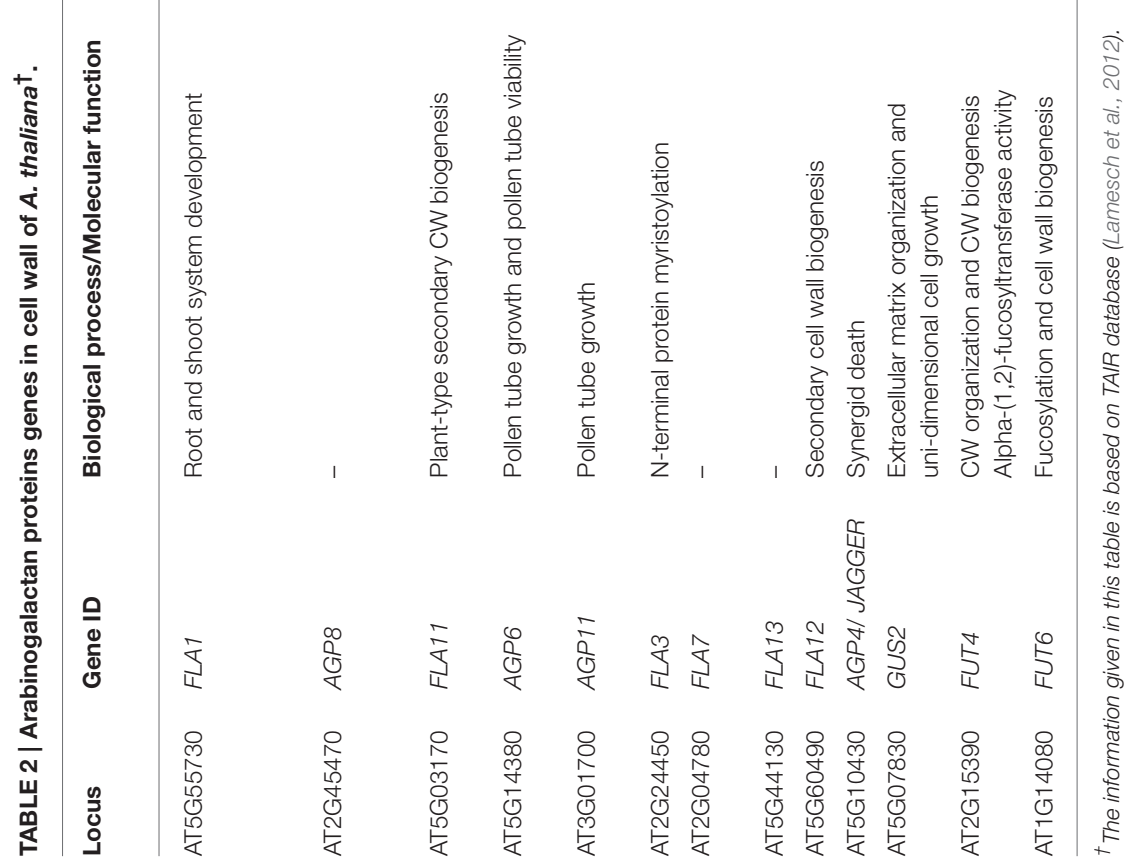


TABLE 3 | Proline rich proteins genes in cell wall of $A$. thaliana ${ }^{\dagger}$.

\begin{tabular}{|c|c|c|c|c|c|}
\hline Locus & Gene ID & $\begin{array}{l}\text { Biological process/Molecular } \\
\text { function }\end{array}$ & Expressed in/Located in & Description & Some of the related references \\
\hline AT1G54970 & PRP1 & Trichoblast differentiation & $\begin{array}{l}\text { Root, root hair cell, trichoblast/CW, } \\
\text { extracellular region }\end{array}$ & Proline-rich protein 1 & Bergonci et al., 2014 \\
\hline AT2G21140 & PRP2 & CW organization & $\begin{array}{l}\text { Leaf, stems, flowers, inflorescence } \\
\text { meristem, stem, guard cell, petal/CW, } \\
\text { extracellular region }\end{array}$ & Proline-rich protein 2 & Panjabi et al., 2008 \\
\hline AT3G62680 & PRP3 & $\begin{array}{l}\text { Cellular responses to auxin stimulus } \\
\text { and calcium ion starvation, and } \\
\text { trichoblast differentiation }\end{array}$ & $\begin{array}{l}\text { Root hair cell, trichoblast/CW, } \\
\text { extracellular region }\end{array}$ & Proline-rich protein 3 & Bergonci et al., 2014 \\
\hline AT4G38770 & PRP4 & Cysteine biosynthetic & $\begin{array}{l}\text { Carpel, sepal, shoot apex, shoot system } \\
\text { flower/CW, extracellular region }\end{array}$ & Proline-rich protein 4 & Panjabi et al., 2008 \\
\hline
\end{tabular}

${ }^{\dagger}$ The information given in this table is based on TAIR database (Lamesch et al., 2012).

\section{TABLE 4 | Glycine rich protein genes in cell wall of $\boldsymbol{A}$. thaliana ${ }^{\dagger}$.}

\begin{tabular}{|c|c|c|c|c|c|}
\hline Locus & Gene ID & $\begin{array}{l}\text { Biological process/Molecular } \\
\text { Function }\end{array}$ & Expression in tissues & Description & $\begin{array}{l}\text { Some of related the } \\
\text { references }\end{array}$ \\
\hline AT4G39260 & GPR8 & $\begin{array}{l}\text { Alternative mRNA splicing, Innate immune } \\
\text { response, responses to ABA, salt stress, } \\
\text { cold/Nucleic acid and nucleotide binding }\end{array}$ & $\begin{array}{l}\text { Carpel, hypocotyl, leaf, juvenile vascular } \\
\text { leaf, flower, fruit, guard cell, plant cell, } \\
\text { plant embryo, seed and seedling } \\
\text { developmental stages, and whole plant }\end{array}$ & $\begin{array}{l}\text { Glycine-rich RNA-binding } \\
\text { protein } 8\end{array}$ & Leder et al., 2014 \\
\hline AT4G18280 & - & - & $\begin{array}{l}\text { Carpel, hypocotyl, leaf, juvenile vascular } \\
\text { leaf, flower, fruit, guard cell, plant cell, } \\
\text { plant embryo, shoot system, root and } \\
\text { whole plant }\end{array}$ & $\begin{array}{l}\text { Glycine-rich cell wall } \\
\text { protein-related }\end{array}$ & Lan et al., 2007 \\
\hline AT3G23830 & GRP4 & Response to cold/RNA and DNA binding & Flower, guard cell, and cotyledon & $\begin{array}{l}\text { Glycine-rich RNA-binding } \\
\text { protein } 4\end{array}$ & Han et al., 2013 \\
\hline AT3G20470 & GRP5 & $\begin{array}{l}\text { Response to ABA or salicylic acid } \\
\text { stimulus, positive regulation of cell } \\
\text { growth/CW structural constituent }\end{array}$ & Carpel, leaf, plant cell, Flower, fruit and leaf & Glycine-rich protein 5 & Mangeon et al., 2010 \\
\hline AT5G07530 & GRP17 & $\begin{array}{l}\text { Lipid storage, pollen hydration, sexual } \\
\text { reproduction/lipid binding }\end{array}$ & $\begin{array}{l}\text { Leaf, petal, pollen, flower, petal, sepal and } \\
\text { stamen }\end{array}$ & Glycine-rich protein 17 & Li-Beisson et al., 2010 \\
\hline AT5G07510 & GRP14 & $\begin{array}{l}\text { Lipid storage, sexual reproduction/Nutrient } \\
\text { reservoir activity }\end{array}$ & $\begin{array}{l}\text { Collective leaf structure, flower, petal and } \\
\text { sepal abundance it express in stems and } \\
\text { with very low abundance it express in } \\
\text { leaves }\end{array}$ & Glycine-rich protein 14 & Li-Beisson et al., 2010 \\
\hline AT5G07520 & GRP18 & $\begin{array}{l}\text { Lipid storage, sexual reproduction/Nutrient } \\
\text { reservoir activity }\end{array}$ & $\begin{array}{l}\text { Collective leaf structure, flower, guard cell, } \\
\text { petal and sepal }\end{array}$ & Glycine-rich protein 18 & Wellmer et al., 2004 \\
\hline AT5G07550 & GRP19 & $\begin{array}{l}\text { Lipid storage, sexual reproduction/lipid } \\
\text { binding }\end{array}$ & $\begin{array}{l}\text { Carpel, cauline leaf, collective leaf } \\
\text { structure, flower, petal, sepal and stamen }\end{array}$ & Glycine-rich protein 19 & Peiffer et al., 2008 \\
\hline AT5G07540 & GRP16 & $\begin{array}{l}\text { Lipid storage, sexual reproduction/lipid } \\
\text { binding }\end{array}$ & $\begin{array}{l}\text { Carpel, collective leaf structure, flower, } \\
\text { petal, sepal and stamen }\end{array}$ & Glycine-rich protein 16 & Ehlting et al., 2008 \\
\hline AT2G15340 & & - & $\begin{array}{l}\text { Collective leaf structure, petal, flower, and } \\
\text { pollen tube }\end{array}$ & Glycine-rich protein & Wang et al., 2008 \\
\hline AT1G48410 & AGO1 & $\begin{array}{l}\text { Leaf proximal, distal pattern } \\
\text { formation/miRNA and protein binding }\end{array}$ & Carpel, leaf lamina, and inflorescence & Glycine-rich protein & $\begin{array}{l}\text { Micol-Ponce et al., } \\
2014\end{array}$ \\
\hline AT3G15400 & ATA20 & & $\begin{array}{l}\text { Carpel, cauline leaf, collective leaf } \\
\text { structure, flower, petal, sepal and guard } \\
\text { cell }\end{array}$ & $\begin{array}{l}\text { Anther } 20 \text {. Encodes a } \\
\text { protein with novel repeat } \\
\text { sequences and a } \\
\text { glycine-rich domain, } \\
\text { which has a } 53 \% \text { identity } \\
\text { to GRP1, a petunia } \\
\text { glycine-rich CW protein }\end{array}$ & Xu et al., 2010 \\
\hline
\end{tabular}

\footnotetext{
${ }^{\dagger}$ The information given in this table is based on TAIR database (Lamesch et al., 2012).
} 
TABLE 5 | Multiple function proline based genes in cell wall of $A$. thaliana ${ }^{\dagger}$.

\begin{tabular}{|c|c|c|c|c|c|}
\hline Locus & Gene ID & $\begin{array}{l}\text { Biological process/Molecular } \\
\text { function }\end{array}$ & Expressed in & Description & $\begin{array}{l}\text { Some of the related } \\
\text { references }\end{array}$ \\
\hline AT5G14800 & P5C1 & $\begin{array}{l}\text { Proline biosynthetic } \\
\text { process/Pyrroline-5-carboxylate } \\
\text { reductase activity }\end{array}$ & $\begin{array}{l}\text { Carpel, flower, leaf, guard cell, seed, } \\
\text { shoot apex, root, stamen, pollen tube } \\
\text { cell, and cotyledon }\end{array}$ & $\begin{array}{l}\text { Delta 1-pyrroline-5-carboxylate } \\
\text { reductase }\end{array}$ & Funck et al., 2012 \\
\hline AT4G02330 & PME41 & $\begin{array}{l}\text { CW modification/Pectin esterase } \\
\text { activity }\end{array}$ & $\begin{array}{l}\text { Carpel, flower, leaf, guard cell, seed, } \\
\text { shoot apex, root, stamen, pollen tube } \\
\text { cell and cotyledon }\end{array}$ & $\begin{array}{l}\text { Encodes a pectin methyl esterase } \\
\text { that is sensitive to chilling stress } \\
\text { and brassinosteroid regulation }\end{array}$ & Qu et al., 2011 \\
\hline AT2G19760 & PFN1/PRF1 & $\begin{array}{l}\text { Actin polymerization, cytoskeleton } \\
\text { organization/Actin monomer } \\
\text { binding }\end{array}$ & $\begin{array}{l}\text { Carpel, flower, leaf, guard cell, seed, } \\
\text { shoot apex, root, stamen, pollen tube } \\
\text { cell and cotyledon }\end{array}$ & Profilin 1 & Wang et al., 2009 \\
\hline AT3G25500 & $A F H 1$ & $\begin{array}{l}\text { Actin cytoskeleton } \\
\text { organization/Protein binding }\end{array}$ & $\begin{array}{l}\text { Carpel, flower, leaf, guard cell, seed, } \\
\text { shoot apex, root, stamen, plant } \\
\text { embryo, pollen tube cell and cotyledon }\end{array}$ & $\begin{array}{l}\text { It is involved in signal-transduction } \\
\text { cascade which results in } \\
\text { rearrangement of the actin } \\
\text { cytoskeleton }\end{array}$ & Rosero et al., 2016 \\
\hline AT5G14610 & & ATP binding & $\begin{array}{l}\text { Carpel, flower, leaf, guard cell, seed, } \\
\text { shoot apex, root, stamen, pollen tube } \\
\text { cell and cotyledon }\end{array}$ & $\begin{array}{l}\text { DEAD box RNA helicase family } \\
\text { protein }\end{array}$ & Spencer et al., 2007 \\
\hline AT3G22070 & & - & $\begin{array}{l}\text { Flower, guard cell, inflorescence } \\
\text { meristem, root, seed, shoot apex }\end{array}$ & Proline-rich family like protein & - \\
\hline
\end{tabular}

${ }^{+}$The information given in this table is based on TAIR database (Lamesch et al., 2012).

in plants (Ueki and Citovsky, 2002). The GRPs constitute almost 70\% glycine (Kar et al., 2012). Analysis done by immunocytochemistry has revealed their direct alliance with proto-xylem, where they play a prominent role in repair and stretching phase (Sachetto-Martins et al., 2000). It is perceived that the continuity of glycine rich domains produced beta pleated hydrophobic structure. An in vitro cross-linking experiment in the presence of peroxidases has explored the configuration of networks in Tyr-containing GRPs. Nonetheless, there is further need to do experimentation to generate data to support the characterization of intra and inter molecular networks involving GRPs.

The GRPs are presumed to be involved in promoting expression of genes in plants, exemplified through the involvement of RNA binding GRP gene AtCSG2 and their regulation during flower development (Sachetto-Martins et al., 2000). The plants in which AtCSG2 was silenced due to biotic or abiotic stress showed premature flowering with reduced stamens and abnormal embryo development (Fusaro et al., 2007). The GRPs yet isolated from plants are categorized as CW-GRPs, RNA-GRPs, and cytokeratin like GRPs (Sharma et al., 2012). Analysis conducted through bioinformatics tools has explored 12 genes controlling different types of GRPs in the CW of $A$. thaliana. These genes also perform salient molecular functions in different kinds of cells and plant parts (Table 4). The study has also revealed eight genes, which could not be categorized to any kind of CWPs and the functions of these genes are indicated in Table 5.

\section{GENE CO-EXPRESSION FUNCTIONALITY}

In A. thaliana, 2,700 proteins express 6,200 highly reliable interactions. The interactive maps provided a dynamic approach in better understanding of the plant biological systems and a base for future crop improvement (Braun et al., 2011). The exploitation of co-expression networks in Arabidopsis provides a dimension to mine genes involved in the synthesis of $\mathrm{CW}$ and to unravel the structural hierarchy of $\mathrm{CW}$ in systematic progression (Obayashi and Kinoshita, 2009). Here, we have made queries through PubMed to understand the genes expression and co-expression in a wired way in the $\mathrm{CW}$ through different kinds of structural proteins. Through bioinformatics tools, 58 genes involved in proline based CW regulation were found. The established wired networks showed the genes co-expression, and interaction in structural components, biological processes and molecular functions by regulating the synthesis of proline based $\mathrm{CW}$ proteins. In regulation of biological processes, these genes have shown physical interaction 55.7\%, co-expression $15.6 \%$, genetic interaction $6.9 \%$, shared proteins domains $3.6 \%$, and colocalization $0.6 \%$ (Figure 3). However, in determining cellular components, these genes have revealed physical interaction $7.4 \%$, co-expression $55.9 \%$, genetic interaction $1.1 \%$, shared proteins domains 2.9\%, and co-localization 1.8\%. Moreover, these proteins helped in signal transduction by regulating the molecular functions for which physical interaction $39.0 \%$, coexpression $11.8 \%$, genetic interaction $3.3 \%$, shared proteins domains $14.6 \%$, and co-localization $0.4 \%$ were calculated. 
Similarly, gene networking and interaction, based on biological process, molecular process and cellular component for protein rich protein extensins, GRPs, arabinogalactan proteins, and PRPs indicated the genes co-expression and interaction even when they were considered separately for a particular family of proteins (Figure 4). These wired networks as a whole, are the clusters of genes repertoire, interacting and co-expressing for different kinds of proteins present in the CW. However, out of this treasury of genes, we mined the genes interacting for a particular class of proteins. Therefore, in this complete wired network, we have showed genes, which are interacting for a specific family of proteins as dark (black) spots. However, light spots represented those genes whose interactions were not considered (Figure 4).

The dynamic signals of the environment, triggering the genetic regulatory network, fluctuate continuously in plant's life cycle with varying extent of predictability. Plants are sessile beings, so to cope with such fluctuating environment, they do not show behavioral adaptations but they respond by modulating their development and physiology (Leakey et al., 2009). The percent of expression of these mined genes was found variable $(0-100 \%)$ in different anatomical parts of $A$. thaliana, as it was revealed by heat map constructed through META analysis (Figure 5A). Likewise, fluctuating manifestation of these genes was noticed for different developmental stages (Figure 5B).

A genome array map for 10 representative genes of $A$. thaliana, in 27 anatomical parts at different developmental stages (germination to senescence) was constructed that represented an alteration in gene expression level with changing developmental stages of the plant (Figure 6). A total of 93 proteins (Boudart et al., 2005) have been identified using proteomic and bioinformatics approaches. A comparison of rosette plants revealed the highly cell type specific involvement of CW proteomes regulated by multigenic families. The plant allocates $10 \%$ of their genome $(\sim 2,500$ genes in Arabidopsis) to synthesize and rearrange the CW (McCann et al., 2007) indicated by the study of protein sequential annotation. Nevertheless, the number of mined genes in the $\mathrm{CW}$ of $A$. thaliana are limited but have been justified experimentally for their involvement in the CW formation. However, cis- regulatory DNA and proteins interact to synthesize the organized CW structure, assured by the synthesis and modifications of these basic constituents in a well-maintained and coordinated fashion, by specific enzymatic activities as revealed by transcriptional coordination of their related genes (Brown et al., 2005).

Xylan is involved in the development of secondary CW in plants and its synthesis network possesses a set of highly expressed genes. A comparative co-expression analysis between rice and Arabidopsis disclosed the absence of some gene families that were present in other species, indicating a clear difference in their CWs (Oikawa et al., 2010). Previous research has published numerous studies about gene interactions, gene expression and protein interactions, but now there is a major need to integrate this knowledge to understand the basic features of living organisms that are proceeding in an organized way. The different interactions including gene expression, gene interactions and protein interactions were used to assemble a biological network that has defined the basic principles to wire a network in a chronological way (Beyer et al., 2007).

Based upon available proteomics and genomics data sets of A. thaliana, geneMANIA can be used to estimate their gene function. To study co-expression and positive as well as negative correlation of gene expression profiles, we applied Plant Array Nets, which works equally good for Oryza, Brassica, and Arabidopsis (Warde-Farley et al., 2010) The immense knowledge as an outcome of genome sequencing paves the way to understand the working philosophy of genes in an integrated way on genome sequencing, expression analysis and protein interaction. The transcriptional coordination has been estimated using PCC. By using this method, co-expression relationships between many genes can be estimated, and visualized as a network in which nodes indicate genes whereas connection between nodes represents the transcriptional coordination of genes (Aoki et al., 2007). The PCC method sometimes becomes defective when some biological processes are strongly transcriptionally co-regulated, while other processes are not. In addition to this, a lower value of PCC results in excessively large gene clusters, possessing thousands of genes (Mao et al., 2009).

The PCC for 50 proline based CW regulating selected genes presented a positive and negative co-expression of +0.969 and -0.827 , respectively (Figure 7 ). Hierarchical clustering of genes based on PCC indicated the co-expression of some genes with same intensity at particular developmental stage with altered expression level changing in the developmental stage (Figure 8). The genes that showed co-expression also represented a high degree of functional correlation. Co-expressions studies of genes can be used to identify other genes. For example, in cellulose synthesis, the co-expression approach can be used to identify the genes involved in the synthesis of hemicellulose (Cocuron et al., 2007). Many genes that are transcriptionally associated with the synthesis of the CW have been already studied (Ruprecht et al., 2011). The genetic redundancy needs mutant combinations or knocks down approaches that will focus upon several homologous genes to generate informative phenotypes. In addition to this, detailed comparative transcriptional studies are still required to mine candidate genes for the $\mathrm{CW}$ synthesis.

The co-expression analysis gives one possible caveat of "false positives," which means some genes are co-expressed by chance rather than being functionally related. However, it has been reported that co-expression relationships are often conserved across species (Obayashi and Kinoshita, 2009). Hence, coexpression analysis across species can improve the reliance of co-expression based functional annotation.

Through computational methodologies, we have generated figures highlighting the expression of genes at different plant specific stages. The module-based predictions provide an approach to formulate hypothesis for functionally unknown genes (1,701) in Arabidopsis and other plant species. It also provides a new imminent into the conservation of co-expression and co-regulation (Heyndrickx et al., 2014). Through proteins architecture studies of the CW, we have identified several genes directly and indirectly involved in proteome manufacturing (Yang et al., 2011). In response to heat stress, P5CR launches 
its oxido-reductase activity by producing pyrroline-5-carboxylate reductase enzyme at the vicinity of the cytoplasm and CW. Under the conditions of biotic and abiotic stresses, the gene express itself in $\mathrm{CW}$ compartment by enhancing proline transport and increasing sensitivity against pathogenic stimuli (Bosch et al., 2011). Hence, modifications in CW proteins and proline transport are an indicator of regulation of genes expression under biotic stresses.

For co-expression studies, the bioinformatics tools have been focused on the model plant Arabidopsis by including the major bulk of publicly available microarray datasets. The candidate genes forming the foundation of the existing $A$. thaliana CW regulatory network, have been identified by gene expression profiling (Handakumbura and Hazen, 2012). Genes with similar functionality and overlapping effects, such as expression and regulation of floral developmental and defense related genes in response to biotic stress (Ahmad et al., 2013, 2014), can also be coordinated as indicated by global transcript analysis based upon publicly available microarray datasets. Certainly, through co-expression analysis in A. thaliana, many transcriptionally coordinated genes involved in the formation of CW proteins, cellulose, hemicelluloses and

\section{REFERENCES}

Ahmad, J. N., Pracros, P., Garcion, C., Teyssier, E., Renaudin, J., Hernould, M., et al. (2013). Effects of stolbur phytoplasma infection on DNA methylation processes in tomato plants. Plant Pathol. 62, 205-216. doi: 10.1111/j.1365-3059.2012.02605.x

Ahmad, J. N., Renaudin, J., and Eveillard, S. (2014). Expression of defense genes in stolbur phytoplasma infected tomatoes, and effect of defense stimulators on disease development. Eur. J. Plant Pathol. 139, 39-51. doi: 10.1007/s10658-013-0361-x

Ahmed, A. A. M., Roosens, N., Dewaele, E., Jacobs, M., and Angenon, G. (2015). Overexpression of a novel feedback-desensitized $\Delta 1$-pyrroline-5-carboxylate synthetase increases proline accumulation and confers salt tolerance in transgenic Nicotiana plumbaginifolia. Plant Cell Tissue Organ Cult. 122, 383-393. doi: 10.1007/s11240-015-0776-5

Ahuja, I., de Vos, R. C. H., Rohloff, J., Stoopen, G. M., Halle, K. K., Ahmad, S. J. N., et al. (2016). Arabidopsis myrosinases link the glucosinolate-myrosinase system and the cuticle. Sci. Rep. 6:38990. doi: 10.1038/srep38990

Albenne, C., Canut, H., and Jamet, E. (2013). Plant cell wall proteomics: the leadership of Arabidopsis thaliana. Front. Plant Sci. 4:111. doi: 10.3389/fpls.2013.00111

Alghabari, F., Ihsan, M. Z., Hussain, S., Aishia, G., and Daur, I. (2015). Effect of Rht alleles on wheat grain yield and quality under high temperature and drought stress during booting and anthesis. Environ. Sci. Pollut. Res. 22, 15506-15515. doi: $10.1007 / \mathrm{s} 11356-015-4724-\mathrm{z}$

Alghabari, F., Ihsan, M. Z., Khaliq, A., Hussain, S., Daur, I., Fahad, S., et al. (2016). Gibberellin-sensitive Rht alleles confer tolerance to heat and drought stresses in wheat at booting stage. J. Cereal Sci. 70, 72-78. doi: 10.1016/j.jcs.2016.05.016

Aoki, K., Perlman, M., Lim, J.-M., Cantu, R., Wells, L., and Tiemeyer, M. (2007). Dynamic developmental elaboration of N-linked glycan complexity in the Drosophila melanogaster embryo. J. Biol. Chem. 282, 9127-9142. doi: 10.1074/jbc.M606711200

Armengaud, P., Breitling, R., and Amtmann, A. (2004). The potassium-dependent transcriptome of Arabidopsis reveals a prominent role of jasmonic acid in nutrient signaling. Plant Physiol. 136, 2556-2576. doi: 10.1104/pp.104.046482

Bai, L., Zhou, Y., and Song, C.-P. (2009). Arabidopsis proline-rich extensin-like receptor kinase 4 modulates the early event toward abscisic acid response in root tip growth. Plant Signal. Behav. 4, 1075-1077. doi: 10.4161/psb.4.11.9739 lignin have been identified. To facilitate this co-expression analysis, several helpful web based tools have been developed for the researchers to investigate transcriptional co-ordinations as well as to mine the candidate genes involved in the CW integrity. In addition, several tools paved the foundation to make comparative transcriptional analysis across many species, which will potentially increase predictive power about gene functionality.

\section{AUTHOR CONTRIBUTIONS}

ZA, JNA, and MI came up with the ideas and reviewed all the literature; MI, SJNA, ZS, and HR took part in writing the manuscript. IA, JNA, and AMB reviewed, critically analyzed and edited the manuscript. All authors discussed and commented on the manuscript.

\section{ACKNOWLEDGMENTS}

AMB, JNA, SJNA, and IA acknowledge the financial support from PAK 3004 Framework for Pak-Norway Institutional Co-operation Programme.

Baluška, F., Šamaj, J., Wojtaszek, P., Volkmann, D., and Menzel, D. (2003). Cytoskeleton-plasma membrane-cell wall continuum in plants. Emerging links revisited. Plant Physiol. 133, 482-491. doi: 10.1104/pp.103.027250

Barceló, A. R., and Laura, V. R. G. (2009). "Reactive oxygen species in plant cell walls," in Reactive Oxygen Species in Plant Signaling, eds A. L. Rio and A. Puppo (Berlin; Heidelberg: Springer), 73-93.

Battaglia, M., Solórzano, R. M., Hernández, M., Cuéllar-Ortiz, S., García-Gómez, B., Márquez, J., et al. (2007). Proline-rich cell wall proteins accumulate in growing regions and phloem tissue in response to water deficit in common bean seedlings. Planta 225, 1121-1133. doi: 10.1007/s00425-0060423-9

Bayer, E. M., Bottrill, A. R., Walshaw, J., Vigouroux, M., Naldrett, M. J., Thomas, C. L., et al. (2006). Arabidopsis cell wall proteome defined using multidimensional protein identification technology. Proteomics 6, 301-311. doi: 10.1002/pmic. 200500046

Bellincampi, D., Cervone, F., and Lionetti, V. (2014). Plant cell wall dynamics and wall-related susceptibility in plant-pathogen interactions. Front. Plant Sci. 5:228. doi: 10.3389/fpls.2014.00228

Bergonci, T., Ribeiro, B., Ceciliato, P. H. O., Guerrero-Abad, J. C., Silva-Filho, M. C., and Moura, D. S. (2014). Arabidopsis thaliana RALF1 opposes brassinosteroid effects on root cell elongation and lateral root formation. J. Exp. Bot. 65, 2219-2230. doi: 10.1093/jxb/ eru099

Beyer, A., Bandyopadhyay, S., and Ideker, T. (2007). Integrating physical and genetic maps: from genomes to interaction networks. Nat. Rev. Genet. 8, 699-710. doi: $10.1038 / \mathrm{nrg} 2144$

Boron, A. K., Van Orden, J., Nektarios Markakis, M., Mouille, G., Adriaensen, D., Verbelen, J.-P., et al. (2014). Proline-rich protein-like PRPL1 controls elongation of root hairs in Arabidopsis thaliana. J. Exp. Bot. 65, 5485-5495. doi: 10.1093/jxb/eru308

Bosch, M., Mayer, C.-D., Cookson, A., and Donnison, I. S. (2011). Identification of genes involved in cell wall biogenesis in grasses by differential gene expression profiling of elongating and non-elongating maize internodes. J. Exp. Bot. 62, 3545-3561. doi: 10.1093/jxb/err045

Boudart, G., Jamet, E., Rossignol, M., Lafitte, C., Borderies, G., Jauneau, A., et al. (2005). Cell wall proteins in apoplastic fluids of Arabidopsis thaliana rosettes: identification by mass spectrometry and bioinformatics. Proteomics 5, 212-221. doi: $10.1002 /$ pmic. 200400882 
Braun, J. E., Huntzinger, E., Fauser, M., and Izaurralde, E. (2011). GW182 proteins directly recruit cytoplasmic deadenylase complexes to miRNA targets. Mol. Cell 44, 120-133. doi: 10.1016/j.molcel.2011.09.007

Brown, D. M., Zeef, L. A. H., Ellis, J., Goodacre, R., and Turner, S. R. (2005). Identification of novel genes in Arabidopsis involved in secondary cell wall formation using expression profiling and reverse genetics. Plant Cell 17, 2281-2295. doi: 10.1105/tpc.105.031542

Bruex, A., Kainkaryam, R. M., Wieckowski, Y., Kang, Y. H., Bernhardt, C., Xia, Y., et al. (2012). A gene regulatory network for root epidermis cell differentiation in Arabidopsis. PLoS Genet. 8:e1002446. doi: 10.1371/journal.pgen.1002446

Businge, E., and Egertsdotter, U. (2014). A possible biochemical basis for fructoseinduced inhibition of embryo development in Norway spruce (Picea abies). Tree Physiol. 34, 657-669. doi: 10.1093/treephys/tpu053

Cannon, M. C., Terneus, K., Hall, Q., Tan, L., Wang, Y., Wegenhart, B. L., et al. (2008). Self-assembly of the plant cell wall requires an extensin scaffold. Proc. Natl. Acad. Sci. U.S.A. 105, 2226-2231. doi: 10.1073/pnas.0711980105

Chardon, F., Virlon, B., Moreau, L., Falque, M., Joets, J., Decousset, L., et al. (2004). Genetic architecture of fowering time in maize as inferred from quantitative trait loci meta-analysis and synteny conservation with the rice genome. Genetics 168, 2169-2185. doi: 10.1534/genetics.104.032375

Chen, J. B., Wang, S. M., Jing, R. L., and Mao, X. G. (2009). Cloning the PvP5CS gene from common bean (Phaseolus vulgaris) and its expression patterns under abiotic stresses. J. Plant Physiol. 166, 12-19. doi: 10.1016/j.jplph.2008.02.010

Choe, H.-T., and Cosgrove, D. J. (2010). "Expansins as agents in hormone action," in Plant hormones: Biosynthesis, Signal Transduction, Action! ed P. J. Davies (Dordrecht: Springer), 262-281.

Cocuron, J.-C., Lerouxel, O., Drakakaki, G., Alonso, A. P., Liepman, A. H., Keegstra, K., et al. (2007). A gene from the cellulose synthase-like C family encodes a $\beta-1,4$ glucan synthase. Proc. Natl. Acad. Sci. U.S.A. 104, 8550-8555. doi: 10.1073/pnas.0703133104

Costa, M., Nobre, M. S., Becker, J. D., Masiero, S., Amorim, M. I., Pereira, L. G., et al. (2013). Expression-based and co-localization detection of arabinogalactan protein 6 and arabinogalactan protein 11 interactors in Arabidopsis pollen and pollen tubes. BMC Plant Biol. 13:7. doi: 10.1186/1471-2229-13-7

de Caestecker, M. P., Yahata, T., Wang, D., Parks, W. T., Huang, S., Hill, C. S., et al. (2000). The Smad4 activation domain (SAD) is a proline-rich, p300dependent transcriptional activation domain. J. Biol. Chem. 275, 2115-2122. doi: 10.1074/jbc.275.3.2115

de Souza Cândido, E., Pinto, M. F. S., Pelegrini, P. B., Lima, T. B., Silva, O. N., Pogue, R., et al. (2011). Plant storage proteins with antimicrobial activity: novel insights into plant defense mechanisms. FASEB J. 25, 3290-3305. doi: 10.1096/fj.11-184291

Diet, A., Link, B., Seifert, G. J., Schellenberg, B., Wagner, U., Pauly, M., et al. (2006). The Arabidopsis root hair cell wall formation mutant lrx1 is suppressed by mutations in the RHM1 gene encoding a UDP-1-rhamnose synthase. Plant Cell 18, 1630-1641. doi: 10.1105/tpc.105.038653

Dinneny, J. R., Long, T. A., Wang, J. Y., Jung, J. W., Mace, D., Pointer, S., et al. (2008). Cell identity mediates the response of Arabidopsis roots to abiotic stress. Science 320, 942-945. doi: 10.1126/science.1153795

Ehlting, J., Sauveplane, V., Olry, A., Ginglinger, J.-F., Provart, N. J., and WerckReichhart, D. (2008). An extensive (co-)expression analysis tool for the cytochrome P450 superfamily in Arabidopsis thaliana. BMC Plant Biol. 8:47. doi: 10.1186/1471-2229-8-47

Ellis, M., Egelund, J., Schultz, C. J., and Bacic, A. (2010). Arabinogalactanproteins: key regulators at the cell surface? Plant Physiol. 153, 403-419. doi: 10.1104/pp.110.156000

Fincher, G. B., Stone, B. A., and Clarke, A. E. (1983). Arabinogalactan-proteins: structure, biosynthesis, and function. Annu. Rev. Plant Physiol. 34, 47-70. doi: 10.1146/annurev.pp.34.060183.000403

Fowler, T. J., Bernhardt, C., and Tierney, M. L. (1999). Characterization and expression of four proline-rich cell wall protein genes in Arabidopsis encoding two distinct subsets of multiple domain proteins. Plant Physiol. 121, 1081-1091. doi: 10.1104/pp.121.4.1081

Francisco, S. M. K.-S., and Tierney, M. L. (1990). Isolation and characterization of a proline-rich cell wall protein from soybean seedlings. Plant Physiol. 94, 1897-1902. doi: 10.1104/pp.94.4.1897

Fry, S. C. (1998). Oxidative scission of plant cell wall polysaccharides by ascorbateinduced hydroxyl radicals. Biochem. J. 332, 507-515. doi: 10.1042/bj3320507
Funck, D., Winter, G., Baumgarten, L., and Forlani, G. (2012). Requirement of proline synthesis during Arabidopsis reproductive development. BMC Plant Biol. 12:191. doi: 10.1186/1471-2229-12-191

Fusaro, A. F., Bocca, S. N., Ramos, R. L. B., Barrôco, R. M., Magioli, C., Jorge, V. C., et al. (2007). AtGRP2, a cold-induced nucleo-cytoplasmic RNA-binding protein, has a role in flower and seed development. Planta 225, 1339-1351. doi: 10.1007/s00425-006-0444-4

Gaspar, Y., Johnson, K. L., McKenna, J. A., Bacic, A., and Schultz, C. J. (2001). The complex structures of arabinogalactan-proteins and the journey towards understanding function. Plant Mol. Biol. 47, 161-176. doi: 10.1023/A:1010683432529

Geilfus, C.-M., Zörb, C., and Mühling, K. H. (2010). Salt stress differentially affects growth-mediating $\beta$-expansins in resistant and sensitive maize (Zea mays L.). Plant Physiol. Biochem. 48, 993-998. doi: 10.1016/j.plaphy.2010.09.011

Geshi, N., Johansen, J. N., Dilokpimol, A., Rolland, A., Belcram, K., Verger, S., et al. (2013). A galactosyltransferase acting on arabinogalactan protein glycans is essential for embryo development in Arabidopsis. Plant J. 76, 128-137. doi: $10.1111 /$ tpj. 12281

Gupta, A. K., and Kaur, N. (2005). Sugar signalling and gene expression in relation to carbohydrate metabolism under abiotic stresses in plants. J. Biosci. 30, 761-776. doi: 10.1007/BF02703574

Han, J. H., Jung, Y. J., Lee, H.-J., Jung, H. S., Lee, K. O., and Kang, H. (2013). The RNA chaperone and protein chaperone activity of Arabidopsis glycinerich RNA-binding protein 4 and 7 is determined by the propensity for the formation of high molecular weight complexes. Protein J. 32, 449-455. doi: 10.1007/s10930-013-9504-3

Hanada, K., Sawada, Y., Kuromori, T., Klausnitzer, R., Saito, K., Toyoda, T., et al. (2011). Functional compensation of primary and secondary metabolites by duplicate genes in Arabidopsis thaliana. Mol. Biol. Evol. 28, 377-382. doi: 10.1093/molbev/msq204

Handakumbura, P. P., and Hazen, S. P. (2012). Transcriptional regulation of grass secondary cell wall biosynthesis: playing catch-up with Arabidopsis thaliana. Front. Plant Sci. 3:74. doi: 10.3389/fpls.2012.00074

Heyndrickx, K. S., De Velde, J. V., Wang, C., Weigel, D., and Vandepoele, K. (2014). A functional and evolutionary perspective on transcription factor binding in Arabidopsis thaliana. Plant Cell 26, 3894-3910. doi: 10.1105/tpc.114.130591

Hsu, H.-C., Lee, Y.-L., Cheng, T.-S., Howng, S.-L., Chang, L.-K., Lu, P.-J., et al. (2005). Characterization of two non-testis-specific CABYR variants that bind to GSK3 $\beta$ with a proline-rich extensin-like domain. Biochem. Biophys. Res. Commun. 329, 1108-1117. doi: 10.1016/j.bbrc.2005.02.089

Hu, Y., Qin, Y., and Zhao, J. (2006). Localization of an arabinogalactan protein epitope and the effects of Yariv phenylglycoside during zygotic embryo development of Arabidopsis thaliana. Protoplasma 229, 21-31. doi: 10.1007/s00709-006-0185-z

Humphrey, T. V., Haasen, K. E., Aldea-Brydges, M. G., Sun, H., Zayed, Y., Indriolo, E., et al. (2014). PERK-KIPK-KCBP signalling negatively regulates root growth in Arabidopsis thaliana. J. Exp. Bot. 66, 71-83. doi: 10.1093/jxb/eru390

Ihsan, M. Z., El-Nakhlawy, F. S., and Ismail, S. M. (2015). Water use efficiency, growth and yield of wheat cultivated under competition with Setaria. Planta Daninha 33, 679-687. doi: 10.1590/S0100-83582015000400006

Ihsan, M. Z., El-Nakhlawy, F. S., Ismail, S. M., Fahad, S., and Daur, I. (2016). Wheat phenological development and growth studies as affected by drought and late season high temperature stress under arid environment. Front. Plant Sci. 7:795. doi: 10.3389 /fpls.2016.00795

Irshad, M., Canut, H., Borderies, G., Pont-Lezica, R., and Jamet, E. (2008). A new picture of cell wall protein dynamics in elongating cells of Arabidopsis thaliana: confirmed actors and newcomers. BMC Plant Biol. 8:94. doi: 10.1186/1471-2229-8-94

Jamet, E., Albenne, C., Boudart, G., Irshad, M., Canut, H., and Pont-Lezica, R. (2008). Recent advances in plant cell wall proteomics. Proteomics 8, 893-908. doi: 10.1002/pmic. 200700938

Jamet, E., Canut, H., Boudart, G., and Pont-Lezica, R. F. (2006). Cell wall proteins: a new insight through proteomics. Trends Plant Sci. 11, 33-39. doi: $10.1016 /$ j.tplants.2005.11.006

Jaspers, P., and Kangasjärvi, J. (2010). Reactive oxygen species in abiotic stress signaling. Physiol. Plant. 138, 405-413. doi: 10.1111/j.1399-3054.2009.01321.x

Jia, Q.-S., Zhu, J., Xu, X.-F., Lou, Y., Zhang, Z.-L., Zhang, Z.-P., et al. (2015). Arabidopsis AT-hook protein TEK positively regulates the expression 
of arabinogalactan proteins for nexine formation. Mol. Plant 8, 251-260. doi: 10.1016/j.molp.2014.10.001

Johnson, K. L., Kibble, N. A. J., Bacic, A., and Schultz, C. J. (2011). A fasciclin-Like arabinogalactan-protein (fla) mutant of Arabidopsis thaliana shows defects in shoot regeneration. PLoS ONE 6:e25154. doi: 10.1371/journal.pone.0025154

Kacperska, A. (2004). Sensor types in signal transduction pathways in plant cells responding to abiotic stressors: do they depend on stress intensity? Physiol. Plant. 122, 159-168. doi: 10.1111/j.0031-9317.2004.00388.x

Kar, B., Nayak, S., and Joshi, R. K. (2012). Classification and comparative analysis of Curcuma longa L. expressed sequences tags (ESTs) encoding glycine-rich proteins (GRPs). Bioinformation 8, 142-146. doi: 10.6026/97320630008142

Keegstra, K., Talmadge, K. W., Bauer, W. D., and Albersheim, P. (1973). The structure of plant cell walls: III. A model of the walls of suspensioncultured sycamore cells based on the interconnections of the macromolecular components. Plant Physiol. 51, 188-197. doi: 10.1104/pp.51.1.188

Kitazawa, K., Tryfona, T., Yoshimi, Y., Hayashi, Y., Kawauchi, S., Antonov, L., et al. (2013). $\beta$-galactosyl yariv reagent binds to the $\beta$-1,3-galactan of arabinogalactan proteins. Plant Physiol. 161, 1117-1126. doi: 10.1104/pp.112.211722

Kwan, J. S., and Morvan, H. (1995). Characterization of extracellular $\beta(1,4)$-xylan backbone O-substituted by arabinogalactans type II in a plant cell suspension. Carbohydr. Polym. 26, 99-107. doi: 10.1016/0144-8617(94)00098-E

Lamesch, P., Berardini, T. Z., Li, D., Swarbreck, D., Wilks, C., Sasidharan, R., et al. (2012). The Arabidopsis Information Resource (TAIR): improved gene annotation and new tools. Nucleic Acids Res. 40, D1202-D1210. doi: $10.1093 / \mathrm{nar} / \mathrm{gkr} 1090$

Lamport, D. T. A., Kieliszewski, M. J., and Showalter, A. M. (2006). Salt stress upregulates periplasmic arabinogalactan proteins: using salt stress to analyse AGP function. New Phytol. 169, 479-492. doi: 10.1111/j.1469-8137. 2005.01591.x

Lamport, D. T. A., Kieliszewski, M. J., Chen, Y., and Cannon, M. C. (2011). Role of the extensin superfamily in primary cell wall architecture. Plant Physiol. 156, 11-19. doi: 10.1104/pp.110.169011

Lan, H., Carson, R., Provart, N. J., and Bonner, A. J. (2007). Combining classifiers to predict gene function in Arabidopsis thaliana using large-scale gene expression measurements. BMC Bioinformatics 8:358. doi: 10.1186/14712105-8-358

Leakey, A. D. B., Ainsworth, E. A., Bernacchi, C. J., Rogers, A., Long, S. P., and Ort, D. R. (2009). Elevated CO2 effects on plant carbon, nitrogen, and water relations: six important lessons from FACE. J. Exp. Bot. 60, 2859-2876. doi: $10.1093 / \mathrm{jxb} / \mathrm{erp} 096$

Leder, V., Lummer, M., Tegeler, K., Humpert, F., Lewinski, M., Schüttpelz, M., et al. (2014). Mutational definition of binding requirements of an hnRNP-like protein in Arabidopsis using fluorescence correlation spectroscopy. Biochem. Biophys. Res. Commun. 453, 69-74. doi: 10.1016/j.bbrc.2014.09.056

Léonard, R., Wopfner, N., Pabst, M., Stadlmann, J., Petersen, B. O., Duus, J. $\varnothing$., et al. (2010). A new allergen from ragweed (Ambrosia artemisiifolia) with homology to art v 1 from mugwort. J. Biol. Chem. 285, 27192-27200. doi: $10.1074 /$ jbc.M110.127118

Lev, S. (2010). Non-vesicular lipid transport by lipid-transfer proteins and beyond. Nat. Rev. Mol. Cell Biol. 11, 739-750. doi: 10.1038/nrm2971

Liang, S., Zheng, D., Standley, D. M., Guo, H., and Zhang, C. (2013). A novel function prediction approach using protein overlap networks. Syst. Biol. 7:61. doi: 10.1186/1752-0509-7-61

Li-Beisson, Y., Shorrosh, B., Beisson, F., Andersson, M. X., Arondel, V., Bates, P. D., et al. (2010). Acyl-lipid metabolism. Arabidopsis Book 8:e0133. doi: 10.1199/tab.0133

Lodish, H., Berk, A., Zipursky, S. L., Matsudaira, P., Baltimore, D., and Darnell, J. (1999). Molecular Cell Biology, 4th Edn. New York, NY: W. H. Freeman.

Ma, H., and Zhao, J. (2010). Genome-wide identification, classification, and expression analysis of the arabinogalactan protein gene family in rice (Oryza sativa L.). J. Exp. Bot. 61, 2647-2668. doi: 10.1093/jxb/erq104

Ma, S., and Bohnert, H. J. (2007). Integration of Arabidopsis thaliana stress-related transcript profiles, promoter structures, and cell-specific expression. Genome Biol. 8:R49. doi: 10.1186/gb-2007-8-4-r49

Macmillan, C. P., Mansfield, S. D., Stachurski, Z. H., Evans, R., and Southerton, S. G. (2010). Fasciclin-like arabinogalactan proteins: specialization for stem biomechanics and cell wall architecture in Arabidopsis and Eucalyptus. Plant J. 62, 689-703. doi: 10.1111/j.1365-313X.2010.04181.x
Majewska-Sawka, A., and Nothnagel, E. A. (2000). The multiple roles of arabinogalactan proteins in plant development. Plant Physiol. 122, 3-10. doi: $10.1104 /$ pp.122.1.3

Mangeon, A., Magioli, C., Tarré, É., Cardeal, V., Araujo, C., Falkenbach, E., et al. G. (2010). The tissue expression pattern of the AtGRP5 regulatory region is controlled by a combination of positive and negative elements. Plant Cell Rep. 29, 461-471. doi: 10.1007/s00299-010-0835-7

Mao, Y., Ge, X., Frank, C. L., Madison, J. M., Koehler, A. N., Doud, M. K., et al. (2009). DISC1 regulates neural progenitor proliferation via modulation of GSK3 $\beta / \beta$-catenin signaling. Cell 136, 1017-1031. doi: 10.1016/j.cell.2008.12.044

McCann, M. C., Defernez, M., Urbanowicz, B. R., Tewari, J. C., Langewisch, T., Olek, A., et al. (2007). Neural network analyses of infrared spectra for classifying cell wall architectures. Plant Physiol. 143, 1314-1326. doi: 10.1104/pp.106.093054

Micheli, F. (2001). Pectin methylesterases: cell wall enzymes with important roles in plant physiology. Trends Plant Sci. 6, 414-419. doi: 10.1016/S1360-1385(01)02045-3

Micol-Ponce, R., Aguilera, V., and Ponce, M. R. (2014). A genetic screen for suppressors of a hypomorphic allele of Arabidopsis ARGONAUTE1. Sci. Rep. 4:5533. doi: $10.1038 /$ srep05533

Mollet, J.-C., Kim, S., Jauh, G.-Y., and Lord, M. E. (2002). Arabinogalactan proteins, pollen tube growth, and the reversible effects of Yariv phenylglycoside. Protoplasma 219, 89-98. doi: 10.1007/s007090200009

Nemoto, K., Seto, T., Takahashi, H., Nozawa, A., Seki, M., Shinozaki, K. et al. (2011). Autophosphorylation profiling of Arabidopsis protein kinases using the cell-free system. Phytochemistry 72, 1136-1144. doi: 10.1016/j.phytochem.2011.02.029

Neto, L. B., De Oliveira, R. R., Wiebke-Strohm, B., Bencke, M., Weber, R. L. M., Cabreira, C., et al. (2013). Identification of the soybean HyPRP family and specific gene response to Asian soybean rust disease. Genet. Mol. Biol. 36, 214-224. doi: 10.1590/S1415-47572013005000017

Nguema-Ona, E., Vicré-Gibouin, M., Gotté, M., Plancot, B., Lerouge, P., Bardor, M., et al. (2014). Cell wall O-glycoproteins and N-glycoproteins: biosynthesis and some functional aspects. Front. Plant Sci. 5:499. doi: $10.3389 /$ fpls.2014.00499

Nishimura, E., Jumyo, S., Arai, N., Kanna, K., Kume, M., Nishikawa, J.-I., et al. (2014). Structural and functional characteristics of S-like ribonucleases from carnivorous plants. Planta 240, 147-159. doi: 10.1007/s00425-014-2072-8

Northcote, D. H., Goulding, K. J., and Horne, R. W. (1960). The chemical composition and structure of the cell wall of Hydrodictyon africanum Yaman. Biochem. J. 77, 503-508. doi: 10.1042/bj0770503

Obayashi, T., and Kinoshita, K. (2009). Rank of correlation coefficient as a comparable measure for biological significance of gene coexpression. DNA Res. 16, 249-260. doi: 10.1093/dnares/dsp016

Oikawa, A., Joshi, H. J., Rennie, E. A., Ebert, B., Manisseri, C., Heazlewood, J. L., et al. (2010). An integrative approach to the identification of Arabidopsis and rice genes involved in xylan and secondary wall development. PLOS ONE 5:e15481. doi: 10.1371/journal.pone.0015481

Panjabi, P., Jagannath, A., Bisht, N. C., Padmaja, K. L., Sharma, S., Gupta, V., et al. (2008). Comparative mapping of Brassica juncea and Arabidopsis thaliana using Intron polymorphism (IP) markers: homoeologous relationships, diversification and evolution of the $\mathrm{A}, \mathrm{B}$ and $\mathrm{C}$ Brassica genomes. BMC Genomics 9:113. doi: 10.1186/1471-2164-9-113

Peiffer, J. A., Kaushik, S., Sakai, H., Arteaga-Vazquez, M., Sanchez-Leon, N., Ghazal, H., et al. (2008). A spatial dissection of the Arabidopsis floral transcriptome by MPSS. BMC Plant Biol. 8:43. doi: 10.1186/1471-2229-8-43

Penfield, S., Li, Y., Gilday, A. D., Graham, S., and Graham, I. A. (2006). Arabidopsis ABA INSENSITIVE4 regulates lipid mobilization in the embryo and reveals repression of seed germination by the endosperm. Plant Cell 18, 1887-1899. doi: $10.1105 /$ tpc. 106.041277

Pereira, A. M., Nobre, M. S., Pinto, S. C., Lopes, A. L., Costa, M. L., Masiero, S., et al. (2016). "Love Is Strong, and You're so Sweet": JAGGER is essential for persistent synergid degeneration and polytubey block in Arabidopsis thaliana. Mol. Plant 9, 601-614. doi: 10.1016/j.molp.2016.01.002

Plieth, C. (2012). Apoplastic calcium executes a shut-down function on plant peroxidases: a hypothesis. Plant Signal. Behav. 7, 678-681. doi: $10.4161 / p s b .20007$ 
Qu, T., Liu, R., Wang, W., An, L., Chen, T., Liu, G., et al. (2011). Brassinosteroids regulate pectin methylesterase activity and AtPME41 expression in Arabidopsis under chilling stress. Cryobiology 63, 111-117. doi: 10.1016/j.cryobiol.2011.07.003

Renault, H., El Amrani, A., Berger, A., Mouille, G., Soubigou-Taconnat, L., Bouchereau, A., et al. (2013). $\gamma$-Aminobutyric acid transaminase deficiency impairs central carbon metabolism and leads to cell wall defects during salt stress in Arabidopsis roots. Plant Cell Environ. 36, 1009-1018. doi: $10.1111 /$ pce. 12033

Rosero, A., Oulehlová, D., Stillerová, L., Schiebertová, P., Grunt, M., Žárský, V., and Cvrčková, F. (2016). Arabidopsis FH1 formin affects cotyledon pavement cell shape by modulating cytoskeleton dynamics. Plant Cell Physiol. 57, 488-504. doi: 10.1093/pcp/pcv209

Ruprecht, C. R., Krarup, A., Reynell, L., Mann, A. M., Brandenberg, O. F., Berlinger, L., et al. (2011). MPER-specific antibodies induce gp120 shedding and irreversibly neutralize HIV-1. J. Exp. Med. 208, 439-454. doi: $10.1084 /$ jem.20101907

Ryser, U., Schorderet, M., Guyot, R., and Keller, B. (2004). A new structural element containing glycine-rich proteins and rhamnogalacturonan I in the protoxylem of seed plants. J. Cell Sci. 117, 1179-1190. doi: 10.1242/jcs.00966

Sachetto-Martins, G., Franco, L. O., and De Oliveira, D. E. (2000). Plant glycinerich proteins: a family or just proteins with a common motif? Biochim. Biophys. Acta Gene Struct. Express. 1492, 1-14. doi: 10.1016/S0167-4781(00) 00064-6

San Clemente, H., and Jamet, E. (2015). WallProtDB, a database resource for plant cell wall proteomics. Plant Methods 11, 1-7. doi: 10.1186/s13007-015-0045-y

Sasidharan, R., Voesenek, L. A. C. J., and Pierik, R. (2011). Cell wall modifying proteins mediate plant acclimatization to biotic and abiotic stresses. Crit. Rev. Plant Sci. 30, 548-562. doi: 10.1080/07352689.2011.615706

Schultz, C. J., Rumsewicz, M. P., Johnson, K. L., Jones, B. J., Gaspar, Y. M., and Bacic, A. (2002). Using genomic resources to guide research directions. The arabinogalactan protein gene family as a test case. Plant Physiol. 129, 1448-1463. doi: 10.1104/pp.003459

Schwager, K. M., Calderon-Villalobos, L. I. A., Dohmann, E. M. N., Willige, B. C., Knierer, S., Nill, C., et al. (2007). Characterization of the VIER FBOX PROTEINE genes from Arabidopsis reveals their Importance for plant growth and development. Plant Cell 19, 1163-1178. doi: 10.1105/tpc.105. 040675

Seifert, G. J., and Roberts, K. (2007). The biology of arabinogalactan proteins. Annu. Rev. Plant Biol. 58, 137-161. doi: 10.1146/annurev.arplant. 58.032806 .103801

Shahzad, A., Muhammad, I., Muhammad, A., Hirani, A. H., and Goyal, A. (2013). Growing wheat on saline lands: can a dream come true? Aust. J. Crop Sci. 7, $515-524$

Sharma, P., Jha, A. B., Dubey, R. S., and Pessarakli, M. (2012). Reactive oxygen species, oxidative damage, and antioxidative defense mechanism in plants under stressful conditions. J. Bot. 2012:217037. doi: 10.1155/2012/217037

Shen, W., Gómez-Cadenas, A., Routly, E. L., Ho, T.-H. D., Simmonds, J. A., and Gulick, P. J. (2001). The salt stress-inducible protein kinase gene, Esi47, from the salt-tolerant wheatgrass Lophopyrum elongatum is involved in plant hormone signaling. Plant Physiol. 125, 1429-1441. doi: 10.1104/pp.125. 3.1429

Showalter, A. M. (1993). Structure and function of plant cell wall proteins. Plant Cell 5, 9-23. doi: 10.1105/tpc.5.1.9

Showalter, A. M., Keppler, B., Lichtenberg, J., Gu, D., and Welch, L. R. (2010). A bioinformatics approach to the identification, classification, and analysis of hydroxyproline-rich glycoproteins. Plant Physiol. 153, 485-513. doi: 10.1104/pp.110.156554

Silva, N. F., and Goring, D. R. (2002). The proline-rich, extensin-like receptor kinase-1 (PERK1) gene is rapidly induced by wounding. Plant Mol. Biol. 50, 667-685. doi: 10.1023/A:1019951120788

Silva-Ortega, C. O., Ochoa-Alfaro, A. E., Reyes-Agüero, J. A., Aguado-Santacruz, G. A., and Jiménez-Bremont, J. F. (2008). Salt stress increases the expression of $\mathrm{p} 5 \mathrm{cs}$ gene and induces proline accumulation in cactus pear. Plant Physiol. Biochem. 46, 82-92. doi: 10.1016/j.plaphy.2007.10.011

Sottosanto, J. B., Gelli, A., and Blumwald, E. (2004). DNA array analyses of Arabidopsis thaliana lacking a vacuolar $\mathrm{Na}+\mathrm{H}+$ antiporter: impact of AtNHX1 on gene expression. Plant J. 40, 752-771. doi: 10.1111/j.1365-313X.2004.02253.x
Spasojević, I., and Pristov, J. B. (2010). The potential physiological implications of polygalacturonic acid-mediated production of superoxide. Plant Signal. Behav. 5, 1525-1529. doi: 10.4161/psb.5.12.12838

Spencer, M. W. B., Casson, S. A., and Lindsey, K. (2007). Transcriptional profiling of the Arabidopsis embryo. Plant Physiol. 143, 924-940. doi: 10.1104/pp.106.087668

Steinwand, B. J., and Kieber, J. J. (2010). The role of receptor-like kinases in regulating cell wall function. Plant Physiol. 153, 479-484. doi: $10.1104 /$ pp. 110.155887

Sultana, N., Florance, H. V., Johns, A., and Smirnoff, N. (2015). Ascorbate deficiency influences the leaf cell wall glycoproteome in Arabidopsis thaliana. Plant Cell Environ. 38, 375-384. doi: 10.1111/pce.12267

Suzuki, H., Oshita, E., Fujimori, N., Nakajima, Y., Kawagoe, Y., and Suzuki, S. (2015). Grape expansins, VvEXPA14 and VvEXPA18 promote cell expansion in transgenic Arabidopsis plant. Plant Cell Tissue Organ Cult. 120, 1077-1085. doi: 10.1007/s11240-014-0662-6

Tan, L., Eberhard, S., Pattathil, S., Warder, C., Glushka, J., Yuan, C., et al. (2013). An Arabidopsis cell wall proteoglycan consists of pectin and arabinoxylan covalently linked to an arabinogalactan protein. Plant Cell 25, 270-287. doi: $10.1105 /$ tpc. 112.107334

Tan, L., Leykam, J. F., and Kieliszewski, M. J. (2003). Glycosylation motifs that direct arabinogalactan addition to arabinogalactan-proteins. Plant Physiol. 132, 1362-1369. doi: 10.1104/pp.103.021766

Tan, L., Qiu, F., Lamport, D. T. A., and Kieliszewski, M. J. (2004). Structure of a hydroxyproline (Hyp)-arabinogalactan polysaccharide from repetitive Ala-Hyp expressed in transgenic Nicotiana tabacum. J. Biol. Chem. 279, 13156-13165. doi: 10.1074/jbc.M311864200

Tan, L., Showalter, A. M., Egelund, J., Hernandez-Sanchez, A., Doblin, M. S., and Bacic, A. (2012). Arabinogalactan-proteins and the research challenges for these enigmatic plant cell surface proteoglycans. Front. Plant Sci. 3:140. doi: $10.3389 /$ fpls.2012.00140

Tryfona, T., Theys, T. E., Wagner, T., Stott, K., Keegstra, K., and Dupree, P. (2014). Characterization of FUT4 and FUT6 $\alpha-(1 \rightarrow 2)$-fucosyltransferases reveals that absence of root arabinogalactan fucosylation increases Arabidopsis root growth salt sensitivity. PLoS ONE 9:e93291. doi: 10.1371/journal.pone.0093291

Ueki, S., and Citovsky, V. (2002). The systemic movement of a tobamovirus is inhibited by a cadmium-ion-induced glycine-rich protein. Nat. Cell Biol. 4, 478-486. doi: 10.1038/ncb806

Velasquez, S. M., Ricardi, M. M., Dorosz, J. G., Fernandez, P. V., Nadra, A. D., PolFachin, L., et al. (2011). O-glycosylated cell wall proteins are essential in root hair growth. Science 332, 1401-1403. doi: 10.1126/science.1206657

Verica, J. A., and He, Z. (2002). The cell wall-associated kinase (WAK) and WAKLike kinase gene family. Plant Physiol. 129, 455-459. doi: 10.1104/pp.011028

Vinocur, B., and Altman, A. (2005). Recent advances in engineering plant tolerance to abiotic stress: achievements and limitations. Curr. Opin. Biotechnol. 16, 123-132. doi: 10.1016/j.copbio.2005.02.001

Voothuluru, P., and Sharp, R. E. (2013). Apoplastic hydrogen peroxide in the growth zone of the maize primary root under water stress. I. Increased levels are specific to the apical region of growth maintenance. J. Exp. Bot. 64, 1223-1233. doi: $10.1093 / \mathrm{jxb} / \mathrm{ers} 277$

Voragen, A. G. J., Coenen, G.-J., Verhoef, R. P., and Schols, H. A. (2009). Pectin, a versatile polysaccharide present in plant cell walls. Struct. Chem. 20, 263-275. doi: 10.1007/s11224-009-9442-z

Wang, F., Jing, Y., Wang, Z., Mao, T., Šamaj, J., Yuan, M., and Ren, H. (2009). Arabidopsis profilin isoforms, PRF1 and PRF2 show distinctive binding activities and subcellular distributions. J. Integr. Plant Biol. 51, 113-121. doi: 10.1111/j.1744-7909.2008.00781.x

Wang, T., Zabotina, O., and Hong, M. (2012). Pectin-cellulose interactions in the Arabidopsis primary cell wall from two-dimensional magic-anglespinning solid-state nuclear magnetic resonance. Biochemistry 51, 9846-9856. doi: $10.1021 /$ bi3015532

Wang, Y., Zhang, W.-Z., Song, L.-F., Zou, J.-J., Su, Z., and Wu, W.-H. (2008). Transcriptome analyses show changes in gene expression to accompany pollen germination and tube growth in Arabidopsis. Plant Physiol. 148, 1201-1211. doi: $10.1104 /$ pp.108.126375

Warde-Farley, D., Donaldson, S. L., Comes, O., Zuberi, K., Badrawi, R., Chao, P., et al. (2010). The GeneMANIA prediction server: biological network integration for gene prioritization and predicting gene function. Nucleic Acids Res. 38, W214-W220. doi: 10.1093/nar/gkq537 
Wellmer, F., Riechmann, J. L., Alves-Ferreira, M., and Meyerowitz, E. M. (2004). Genome-wide analysis of spatial gene expression in Arabidopsis flowers. Plant Cell 16, 1314-1326. doi: 10.1105/tpc.021741

Wolf, S., Hématy, K., and Höfte, H. (2012). Growth control and cell wall signaling in plants. Annu. Rev. Plant Biol. 63, 381-407. doi: 10.1146/annurev-arplant-042811-105449

Wuest, S. E., Vijverberg, K., Schmidt, A., Weiss, M., Gheyselinck, J., Lohr, M., et al. (2010). Arabidopsis female gametophyte gene expression map reveals similarities between plant and animal gametes. Curr. Biol. 20, 506-512. doi: 10.1016/j.cub.2010.01.051

Xu, J., Yang, C., Yuan, Z., Zhang, D., Gondwe, M. Y., Ding, Z., et al. (2010). The ABORTED MICROSPORES regulatory network is required for postmeiotic male reproductive development in Arabidopsis thaliana. Plant Cell 22, 91-107. doi: $10.1105 /$ tpc. 109.071803

Xu, P., Cai, X.-T., Wang, Y., Xing, L., Chen, Q., and Xiang, C.-B. (2014). HDG11 upregulates cell-wall-loosening protein genes to promote root elongation in Arabidopsis. J. Exp. Bot. 65, 4285-4295. doi: 10.1093/jxb/eru202

Yamaguchi, T., and Blumwald, E. (2005). Developing salt-tolerant crop plants: challenges and opportunities. Trends Plant Sci. 12, 615-620. doi: $10.1016 / j . t p l a n t s .2005 .10 .002$

Yan, H., Ma, L., Wang, Z., Lin, Z., Su, J., and Lu, B.-R. (2015). Multiple tissuespecific expression of rice seed-shattering gene $\mathrm{SH} 4$ regulated by its promoter pSH4. Rice 8, 12. doi: 10.1186/s12284-015-0047-4

Yang, X., Ye, C.-Y., Bisaria, A., Tuskan, G. A., and Kalluri, U. C. (2011). Identification of candidate genes in Arabidopsis and Populus cell wall biosynthesis using text-mining, co-expression network analysis and comparative genomics. Plant Sci. 181, 675-687. doi: 10.1016/j.plantsci. 2011.01.020
Ye, Z.-H., Song, Y.-R., Marcus, A., and Varner, J. E. (1991). Comparative localization of three classes of cell wall proteins. Plant J. 1, 175-183. doi: 10.1111/j.1365-313X.1991.00175.x

Yokoyama, A., Yamashino, T., Amano, Y.-I., Tajima, Y., Imamura, A., Sakakibara, H., et al. (2007). Type-B ARR transcription factors, ARR10 and ARR12, are implicated in cytokinin-mediated regulation of protoxylem differentiation in roots of Arabidopsis thaliana. Plant Cell Physiol. 48, 84-96. doi: $10.1093 / \mathrm{pcp} / \mathrm{pcl} 040$

Youl, J. J., Bacic, A., and Oxley, D. (1998). Arabinogalactan-proteins from Nicotiana alata and Pyrus communis contain glycosylphosphatidylinositol membrane anchors. Proc. Natl. Acad. Sci. U.S.A. 95, 7921-7926. doi: 10.1073/pnas.95.14.7921

Zhu, Y., Dong, A., Meyer, D., Pichon, O., Renou, J.-P., Cao, K., et al. (2006). Arabidopsis NRP1 and NRP2 encode histone chaperones and are required for maintaining postembryonic root growth. Plant Cell 18, 2879-2892. doi: $10.1105 /$ tpc. 106.046490

Conflict of Interest Statement: The authors declare that the research was conducted in the absence of any commercial or financial relationships that could be construed as a potential conflict of interest.

Copyright $\odot 2017$ Ihsan, Ahmad, Shah, Rehman, Aslam, Ahuja, Bones and Ahmad. This is an open-access article distributed under the terms of the Creative Commons Attribution License (CC BY). The use, distribution or reproduction in other forums is permitted, provided the original author(s) or licensor are credited and that the original publication in this journal is cited, in accordance with accepted academic practice. No use, distribution or reproduction is permitted which does not comply with these terms. 